\title{
The functional morphology of Penicillus philippinensis (Anomalodesmata: Clavagelloidea: Penicillidae) and the evolution of an unique muscular system in the Bivalvia
}

\author{
Brian Morton \\ Department of Zoology, The Natural History Museum, Cromwell Road, London SW7 5BD, U.K. \\ e-mail: prof_bsmorton@hotmail.com
}

\begin{abstract}
The Indo-West Pacific watering pot shell Penicillus philippinensis (Penicillidae) is essentially amyarian, that is, the posterior adductor and pedal retractor muscles are lost, their anterior equivalents vestigial. In addition to a small group of pallial retractor muscles arising from the pallial line, as is typical of other penicillids, this bivalve is connected to its adventitious tube dorso-laterally by a saddle-shaped array of papillae that previses the more elaborate system in the southern Australian Kendrickiana veitchi. That species and $P$. philippinensis also differ from other penicillids in that their siphons are capable of only limited retraction into the tube. Their extension in both species is largely by hydraulic means, the complex pallial musculature acting antagonistically with extensive blood-filled haemocoels. $P$. philippinensis can also be separated from other penicillids by a number of anatomical characters. For example, some taxa such as $K$. veitchi and Nipponoclava gigantea (but not Foegia novaezelandiae) have vestigial posterior pedal retractor muscles and associated pericardial proprioreceptors but $P$. philippinensis does not. Like other penicillids, however, $P$. philippinensis has a muscular pedal disc whereas $K$. veitchi does not. A trend in the Penicillidae towards even greater specialization for life inside an adventitious tube has arguably culminated in the unique muscular system of $K$. veitchi. $P$. philippinensis indicates how this may have been achieved.
\end{abstract}

\section{INTRODUCTION}

The Anomalodesmata comprises one sixth of all bivalve families (Harper et al. 2000) and these, as currently defined, have been discussed by Morton (2003a) and were last reviewed by Morton (1981, 1985a). Most anomalodesmatans are 'rare'; most are also aberrant and many are quite bizarre, compared with the generality of Bivalvia. Pojeta and Sohl (1987: 1) referred to the Late Cretaceous Ascaulocardium armatum (Morton, 1833) as "the ultimate variation on the bivalve paradigm". A. armatum is a member of the Clavagelloidea, that is, the watering pot shells, which arguably contain the most aberrant of all bivalves and these are currently being examined in some detail by this author to reveal an adaptive radiation not hitherto wholly appreciated (Morton 2002a, b, 2003b, 2004a, b, c).

Representatives of the endobenthic tube-dwelling Clavagelloidea (Penicillidae) are characterised by the loss of the posterior adductor muscle and, sometimes, the anterior, for example, Kendrickiana veitchi (Smith, 1971), and either loss or great reduction of the pedal retractor muscles. Foegia novaezelandiae (Bruguière, 1789), for example, is amyarian (Morton 2004a). Such a loss of musculature has had powerful implications for the mode of life of these animals. This is because, in their absence and with shell valves immovably fused horizontally into the fabric of the adventitious tube, all movements of the body with respect to siphonal extension and retraction, in particular, have to be achieved by the hydraulic pumping into and out of the mantle cavity of supernatant and interstitial water by contractions and relaxations of a muscular pedal disc. This structure acts as a pump to generate the necessary internal hydraulic pressures in the mantle cavity (Purchon 1960) that, in turn, exert equivalent pressures within the blood vascular system, that is, in the complex pallial haemocoels (Morton 1984a, 2002a).

Initially, it was thought that water was pumped out of the watering pot and into the sediment to effect either reburial following disinterment or deeper burrowing (Purchon 1960; Savazzi 1999). It is now known that the principal function of the pedal disc is to pump interstitial water into the mantle cavity (Morton 2002a, 2004a). There are other adaptations to a tube-dwelling mode of life, notably with regard to the development of unique, paired pericardial proprioreceptors that monitor body tonus, possibly either to avoid over-filling of the capacious rectum, as may be the case in 
Brechites vaginiferus (Lamarck, 1818) (Morton 2002a) or, more generally, to enable the body as a whole to be maintained in a state of ambient tonicity, as in Kendrickiana veitchi (Morton, 2004b). Strangely, however, such receptors have hitherto only been identified in epibenthic, cemented clavagelloids, for example, Humphreyia strangei (A. Adams, 1852) and Dianadema multangularis (Tate, 1887) (Morton 2002b, 2003b), and where they are associated with what are probably the surviving vestiges of posterior pedal retractor muscles. They are absent in the endobenthic Brechites vaginiferus and Foegia novaezelandiae, where such muscles are vestigial and lost, respectively (Morton, 2002a, 2004a). In Kendrickiana veitchi and Nipponoclava gigantea Sowerby, 1888, the vestigial posterior pedal retractors form a simple union with the visceral ganglia and possibly function as tonus proprioreceptors (Morton 2004b, c).

The watering pot shells of the Clavagelloidea have long been of interest because of their distinctive structure and figure prominently in early malacological texts (Bruguière 1789; Chenu 1843; Reeve 1860) and were similarly objects of great scientific interest in the $19^{\text {th }}$ century (Owen 1835; Gray 1847, 1858a; Lacaze-Duthiers 1870, 1883). More recently, a number of clavagelloids have been described in greater detail, for example, species of Clavagella (Soliman 1971; Morton 1984b), Bryopa (Appukuttan 1974; Savazzi 2000) and Dianadema (Morton 2003b) (Clavagellidae), and Brechites (Purchon 1956, 1960; Morton 1984a, 2002a), Humphreyia, Foegia, Kendrickiana and Nipponoclava (Morton 1984a, 2002b, 2004a, b, c) (Penicillidae). In addition, Harper and Morton (2004) have described how the penicillid adventitious tube is formed and thereby greatly clarified our understanding of how these unusual animals have been able to adopt their distinctive tube-dwelling lives. Recently, intact specimens of a species of Penicillus were obtained from the collections of the Museum of Comparative Zoology, The Agassiz Museum, Harvard University, and will be described below.

The anatomy of species of Penicillus Bruguière, 1789 have been investigated by Lacaze-Duthiers (1870, 1883), that is, $P$. (as Aspergillum) javanum Chenu, $1843(=P$. philippinensis Bruguière, 1789), $P$. (as Aspergillum) dichotomum Chenu, $1843 \quad(=P$. penis [Linnaeus, 1758]) and Purchon (1956, 1960), that is, $P$. (as Brechites) penis. Such studies were, however, undertaken with no knowledge of the anatomy of any other penicillid genus and thus of the full spectrum of clavagelloid adaptive radiation. Further, the studies were undertaken in the absence of histological information so that important anatomical details remained undescribed. As a consequence, currently published classifications, for example, Smith (1998), place all tube dwelling anomalodesmatans in one family - the Clavagellidae Orbigny, 1844. It has been demonstrated, however, that the Clavagelloidea comprises two families - the Clavagellidae and Penicillidae Bruguière, 1789 - that show remarkable convergent adaptations to a tube-dwelling life (Morton 2004a, b, c).

This paper provides a description of a representative of one of the last genera (Penicillus) to be studied in the light of a better appreciation of the superfamily as a whole, building on the earlier work of Lacaze-Duthiers and Purchon (see above). This study has resulted in a more complete interpretation of the adaptive radiation of the Clavagelloidea, including an understanding of how the unique muscular system of Kendrickiana veitchi evolved (Morton 2004b).

\section{MATERIALS AND METHODS}

What follows is a description of two preserved specimens of Penicillus philippinensis from the collections of the Agassiz Museum, Harvard University (Reg. No. MCZ 1744) and which were collected by $\mathrm{H}$. Cuming from an unknown locality. One specimen was dissected; the entire second specimen was subjected to routine histological procedures and $6 \mu \mathrm{m}$ transverse sections of the entire animal were cut. Every tenth section was stained in either Ehrlich's haematoxylin and eosin or Masson's trichrome. In addition, tubes of putative $P$. philippinensis in the collections of the Western Australian Museum were examined and are also reported upon herein.

\section{TAXONOMY}

According to Keen and Smith (1969), the type species of the genus Penicillus Bruguière, 1789 is $P$. javanus Bruguière, 1789 (= Serpula penis Linnaeus, 1758). Smith (1976), in his revision of the extant Clavagelloidea, concluded that Penicillus was a subgenus of Brechites Guettard, 1770. Keen and Smith (1969) considered this latter genus name to be a nonbinomial synonym of Penicillus. Morton (1984a, 2002a), however, considered Brechites to be sufficiently different from Penicillus to warrant its separation at the generic level. According to Smith (1976) Penicillus comprises two species, that is, the type $P$. penis, and $P$. philippinensis. Chenu (1843) and Reeve (1860) illustrated and described a large number of penicillids, many collected by $\mathrm{H}$. Cuming, and which Smith (1976) and Lamprell and Healy (1998) further considered to be synonyms of either $P$. philippinensis or $P$. penis.

Morton (2004c) showed that Nipponoclava gigantea and other penicillids, for example, Foegia novaezelandiae and Kendrickiana veitchi (Morton, 2004a, b), differ from Penicillus philippinensis in 
terms of adductor and pedal retractor muscle arrangements. The taxonomic arrangement followed herein, therefore, is that the name Brechites should be restricted to its type species, that is, Aspergillum vaginiferum Lamarck, 1818 and that Penicillus (Bruguiere, 1789) should be returned to its original, full generic ranking

\section{Identity of the species herein considered}

The species herein under investigation is considered to be Penicillus philippinensis, as noted above. The two studied specimens were part of a larger lot of 12 preserved individuals held in the collections of the Museum of Comparative Zoology, Harvard University (MCZ). The label of the lot reads only 'Coll. H. Cuming. Ex. J. G. Anthony, 15 Dec. 1863'. It seems possible that the specimens of $P$. philippinensis in MCZ were collected by Cuming and eventually either sold to or exchanged with American shells in the collections of J. G. Anthony.

Cuming made extensive collections in Southeast Asia including the Philippines, Indonesia and Singapore. The holotype of Penicillus philippinensis is a specimen collected by Cuming with the type locality as 'Saint Nicolas, Zebu Island, Philippines'. Smith (1976) provides a map of the distribution of $P$. philippinensis and shows it to range throughout the Philippines, the eastern islands of Indonesia and the eastern half of the South China Sea and from southern Western Australia (Rottnest Island) across northern Australia to central Queensland. Smith (1976) also provides a map of the distribution of $P$. penis. It is described therein as ranging from the Arabian Gulf, the east coast of Africa, across the Indian Ocean to the Andaman Sea, West Malaysia, Thailand, the western islands of Indonesia and East Malaysia, and the western half of the South China Sea and Singapore (Purchon 1956, 1960). Penicillus penis is not known to occur in Australia and it appears therefore that the distributions of the two species are mainly contiguous except for some overlap only in waters of central Southeast Asia. Moreover, only specimens of $P$. penis have been recorded from Singapore and, therefore, the specimens herein under consideration very probably would have come from either the Philippines or Java, Indonesia (from where they are illustrated, as $P$. javanum, by Dharma [1992, plate 26, fig 19]) and, hence, confirming their identity as $P$. philippinensis.

\section{HABITAT NOTES}

Apart from the above description of the distribution of Penicillus philippinensis, there is little other information on it hitherto available except for details of the Australian and other material reported upon by Smith (1971). He cites specimens from off Pratas Island in the South China
Sea in 88 fathoms $(160 \mathrm{~m})$, the southeast coast of Tawi Tawi in 18 fathoms $(33 \mathrm{~m})$ and one in the United States National Museum from an unknown location and a depth of 100 fathoms $(183 \mathrm{~m})$. In the collections of the Western Australian Museum, Perth (WAM), there are a number of specimens of P. philippinensis (as P. strangulatus [Chenu, 1843]). These were collected from Onslow/Broome (WAM Reg. No. 194-71), Gunn Point, east of Darwin (WAM Reg. No. S10849), Torres Strait, Queensland (WAM Reg. No. S15949) and Cape York, Queensland (WAM Reg. No. 600-69) and thus fit into the distribution described by Smith (1976). I have collected one empty tube of $P$. philippinensis from an intertidal sand flat at Dampier, northwestern Western Australia (own collection).

\section{RESULTS}

\section{Anatomy}

\section{The adventitious tube}

The adventitious tubes of specimens of Penicillus philippinensis in the collections of the $\mathrm{MCZ}$, range in length from $66-96 \mathrm{~mm}$ and in greatest width from $7-12 \mathrm{~mm}$. Those in the collections of the WAM range in total length from $80-150 \mathrm{~mm}$ and in greatest width from $7-16 \mathrm{~mm}$. One such adventitious tube is illustrated in Figure 1. The tube is chalky white with only a light covering of sand and other particles along the central part of its shaft. From the watering pot, the tube tapers posteriorly, except that it bulges anterior to and more strongly posterior from the true shell valves (Figure 1A). This is unlike the situation in the congeneric $P$. penis, that tapers smoothly from anterior to posterior (Smith 1971, 1976, figs 21-25). The posterior bulge in $P$. philippinensis houses the main body of the animal, the anterior one the pedal disc. Anteriorly, there is a circular "watering pot". This is seen from the posterior aspect in Figure 1B. Its rim comprises a continuous radiating flange of fused tubules, some of which branch dichotomously (Figure 1F). The central convex element of the watering pot also possesses tubules and there is a central dorso-ventrally aligned pedal gape. Few sand grains and other debris attach to the anterior region of the tube and watering pot. The shaft of the tube containing the siphons accounts for approximately three-quarters of its total length and it ends posteriorly at an 8-shaped siphonal opening (Figure 1C). The adventitious tube is not covered with sand grains posteriorly, suggesting that it projects above the sediment, and shows signs of either growth or repair. In the illustrated specimen, there are two growth/repair increments located close together in the posteriorly naked element of the tube (Figure 1D). Antero-ventrally, as in Brechites vaginiferus (Morton 2002a), there is a 


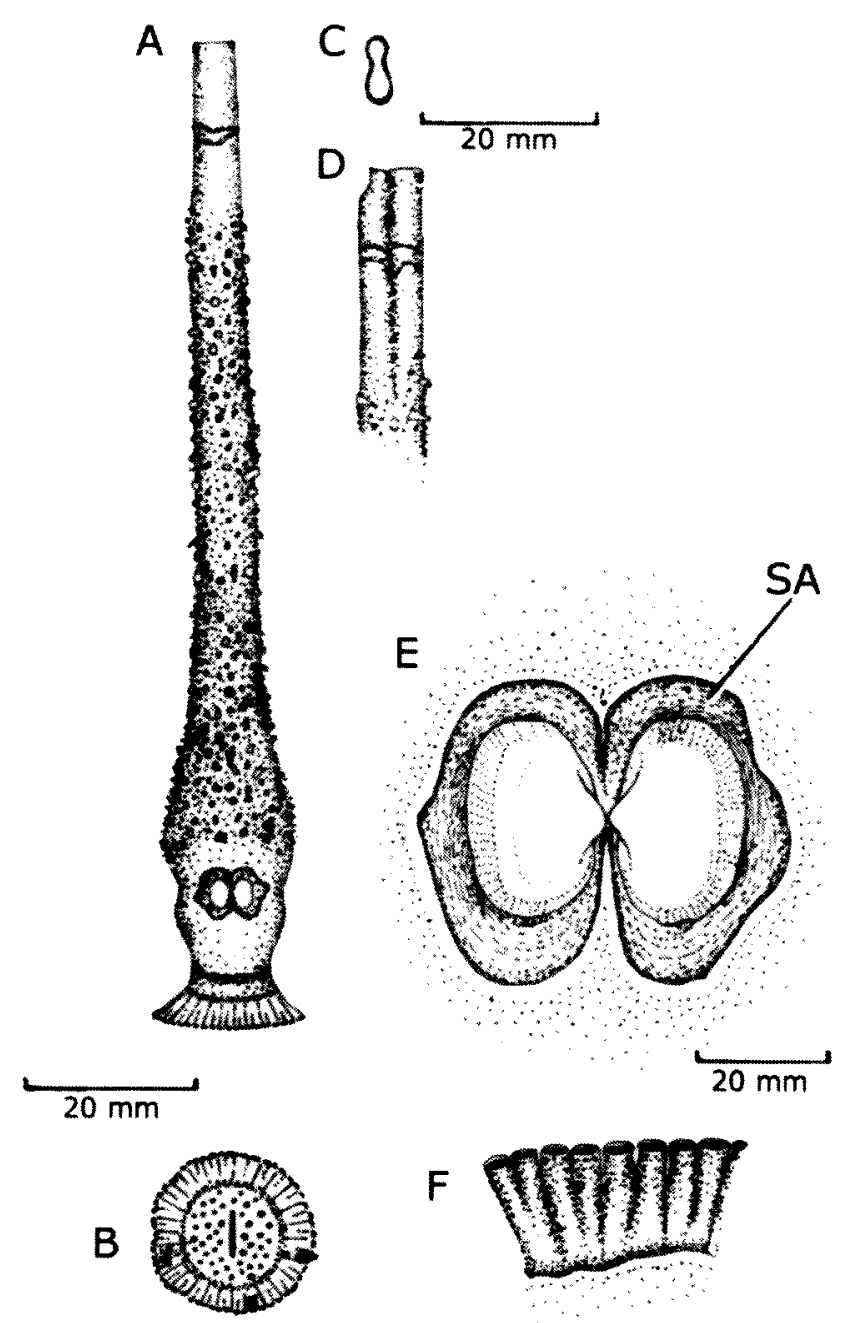

Figure 1 Penicillus philippinensis. The adventitious tube as seen from A, the dorsal; B, the anterior and $C$, the posterior aspects. $D$ is a more detailed view of the posterior siphonal end showing growth/repair increments. E shows the true shell valves and surrounding saddle (SA) in more detail and F, the tubules of the watering pot rim.

"line" separating tube from watering pot, although Harper and Morton (2004) do not believe this to have any significance in terms of tube manufacture and its provenance remains obscure. Where the covering of sand and other particles is eroded from it (Figure 1A), the chalky nature of the tube is more obvious and is covered in a delicate, light-brown periostracum.

Some of the tubes of Penicillus philippinensis in the collections of the WAM have a series of either growth or repair increments, as illustrated in Figures $1 \mathrm{~A}$ and D. Two of these had breaks and repairs just above the watering pot, but in most individuals these were located posteriorly and ranged in number from one to eight and in such cases it is unclear whether these are repairs or growth increments (or both). It seems likely, however, that the posterior extensions represent

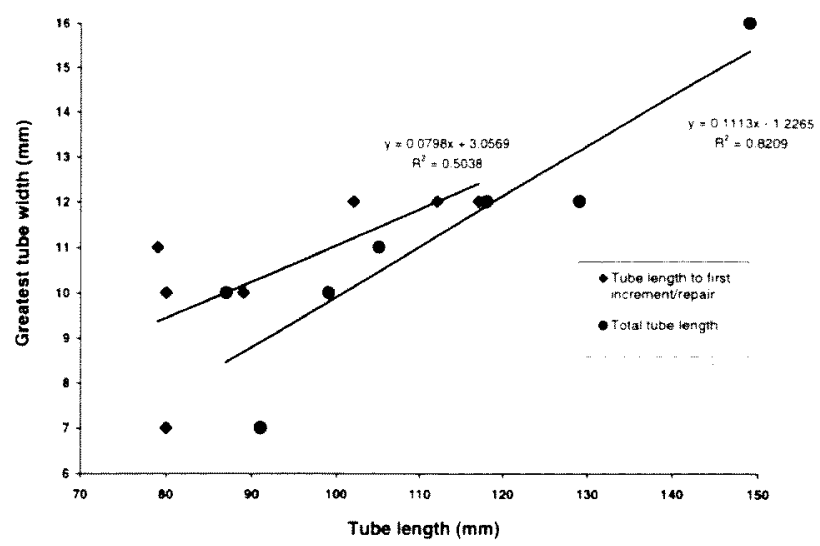

Figure 2 Penicillus philippinensis. The relationships between adventitious tube width and total length $(\bullet)$ and length to the first growth (or repair) increment $(\bullet)$.

damage and repair events but which, in the longer term, also keep the siphonal apertures above the habitat of accretive sand.

The greatest adventitious tube width plotted against (i), total tube length and (ii), tube length to the first break and repair are illustrated in Figure 2. Both are, albeit weak, straight-line relationships that parallel each other approximately. Thus, (i), there is a positive correlation between tube length and width, (ii), tube repairs (or a growth increment) occur at approximately half the maximum tube length and (iii), there is no positive correlation between break length (or increment addition) and tube width. This suggests, as has been proposed and similarly illustrated for other endobenthic penicillids, for example, Brechites vaginiferus, Foegia novaezelandiae and Kendrickiana veitchi (Morton 2002a, 2004a, b), that the main structure of the tube is probably produced only once, as argued by Harper and Morton (2004), but can be added to posteriorly as either repair or growth increments.

\section{The shell valves}

Harper and Morton (2004, fig. 3) describe and illustrate the true shell valves of a specimen of Penicillus pulchrum (Reeve, 1860, species 13) $(=P$. penis) (Smith 1976). The shell valves of $P$. philippinensis are illustrated in Figure $1 \mathrm{~A}$ in relation to the adventitious tube and in greater detail in Figure 1E. As in all clavagelloids, except Nipponoclava gigantea (Morton 2004c), the valves are about $3.5 \mathrm{~mm}$ long and $3.0 \mathrm{~mm}$ high and are equivalve and inequilateral, that is, anteriorly foreshortened and posteriorly elongate. There is a light pattern of radial striae and periostracal spinules as first described for Lyonsia hyalina Conrad, 1848 by Prezant (1979a, 1981). Similar spicules have been reported upon for some representatives of the Laternulidae (Aller 1974; Carter and Aller 1975), Pholadomyidae, 


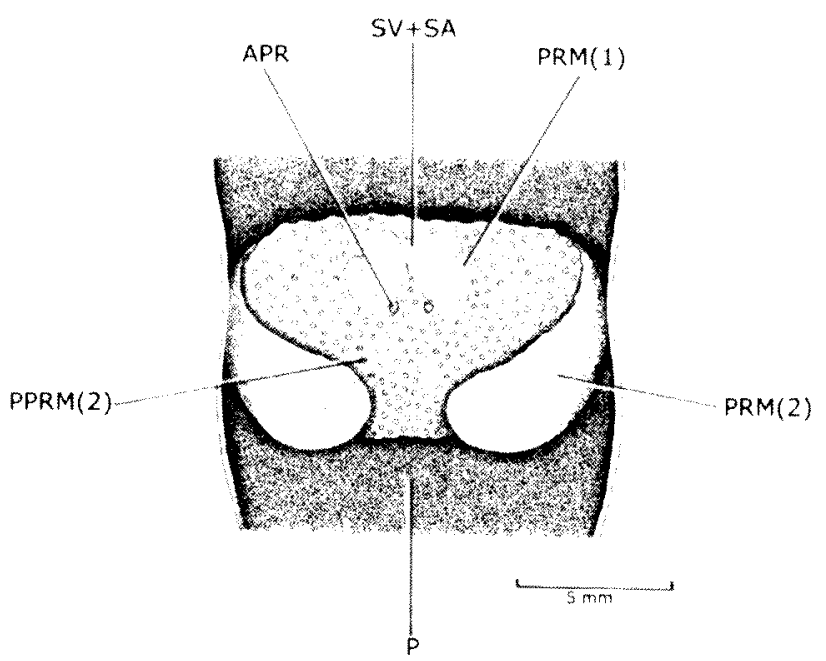

Figure 3 Penicillus philippinensis, An internal view of the adventitious tube showing the 'saddle' of calcareous material secreted beneath the periostracum and its various muscle impressions. For abbreviations see the Appendix.

Parilimyidae, Poromyidae, Thraciidae, Verticordiidae and Lyonsiellidae (Morton 1985 , 2003a). The shell valves of $P$. philippinensis, indeed of all clavagelloids, however, resemble those of representatives of the Lyonsiidae which Dreyer, Steiner and Harper (2003) have shown genetically to be a sister taxon. Where the outer aragonitic layer has been eroded away, the true shell of $P$. philippinensis is seen to be nacreous, as in all other penicillids so far described (Taylor et al. 1973). The two valves are aligned horizontally and surrounded by and united with a "saddle" of shell material that has been secreted subsequently and is characterized by a weak sculpture of irregular concentric growth lines.

As in other penicillids, the shell and saddle of Penicillus philippinensis are hidden internally within the fabric of the adventitious tube by a similarly saddle-shaped coating of aragonite secreted by the dorsal surface of the mantle. In $P$. philippinensis, the shell valve and saddle impressions are indistinct (Figure 3 ) in this internal sheet of secondarily secreted tube material. Similarly, the impressions of the two bean-shaped pallial lines, identifying pallial retractor muscle attachments, and anterior pedal retractor scars are difficult to identify. The internally secreted saddle is, however, distinctly isolated from the remainder of the adventitious tube by the surrounding sheet of periostracum that defines its circumference. Thus, the internal saddle (Figure 1E, SA) is secreted beneath the periostracum and serves the principal function of similar concretions in other penicillids, for example Brechites vaginiferus (Morton 2002a), of binding the shell, external saddle and tube elements into a structurally stronger whole. Unlike these other penicillids, however, dorsally and laterally, just anterior to the position of the true shell and pallial line with pallial retractor muscles, the saddle concretion is lightly dimpled. As will be discussed, this is reminiscent of the internal tube structure of Kendrickiana veitchi (Morton 2004b). As noted above, the periostracal sheet that covers the body of the animal, including the siphons and the pedal disc, arises from the circumference of the internal saddle-shaped concretion. Because of the concretion, however, the correspondingly saddleshaped area of mantle beneath it is not covered in periostracum and, as will be described, is dotted with small papillae.

\section{Internal anatomy}

The anatomy of an individual of Penicillus philippinensis that has been removed from its tube is illustrated in Figure 4. In dorsal view (Figure 4A), the pericardium and its contained organs is the most obvious structure. There is a single ventricle that has paired lateral auricles. The rectum is enclosed by the ventricle of the heart and passes posteriorly over the paired kidneys. Anterior to the pericardium, there is a pair of tiny anterior pedal retractor muscles located on the antero-dorsal edges of the left and right blocks of pallial retractor muscles. Purchon (1956, 1960) did not identify anterior pedal retractor muscles in $P$. (as Brechites) penis. As in Brechites vaginiferus, Foegia novaezelandiae (Morton 2002a, 2004a) and P. penis
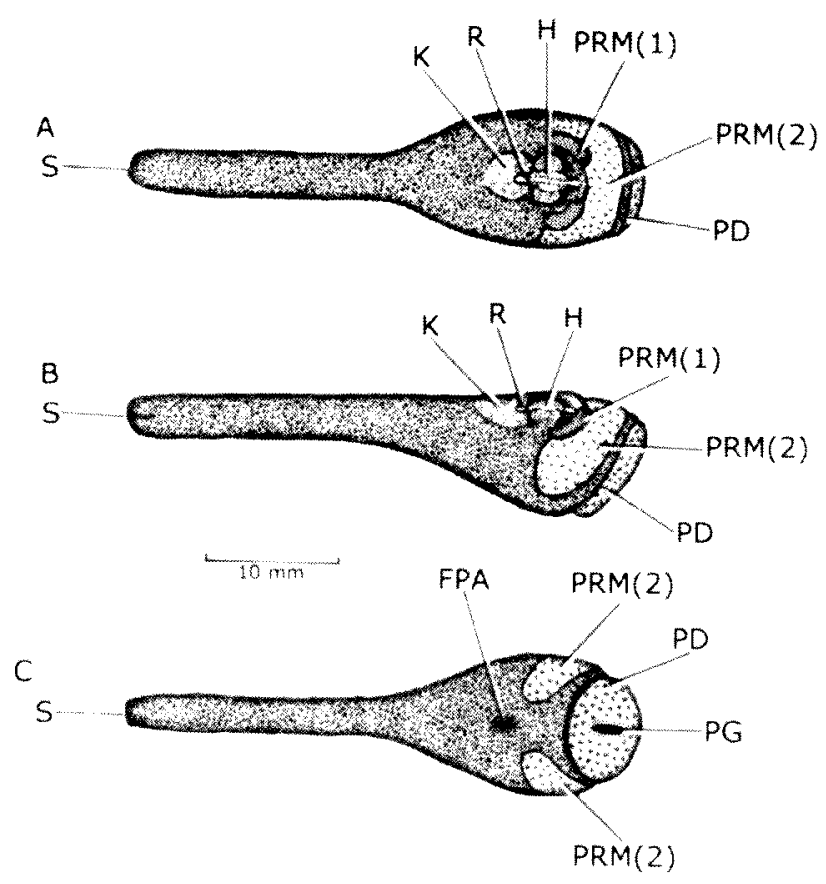

Figure 4 Penicillus philippinensis. View's of an intact individual, as seen from $A$, the dorsal; $B$, right lateral and $C$, ventral aspects. For abbreviations see the Appendix. 
(Purchon 1956), however, there are no posterior pedal retractor muscles.

The pericardium of Penicillus philippinensis is surrounded, except posteriorly, by the saddleshaped array of papillae, the tip of each of which is located in the dimples or slight impressions in the surface of the internal calcareous concretion of the adventitious tube above it. These will be described in detail but are also illustrated in right lateral view in Figure $4 \mathrm{~B}$, and wherein the pedal disc is also seen to be positioned anterior to the saddle of papillae. The circular pedal disc with its dorsoventrally aligned pedal gape is seen from the ventral view in Figure 4C. As in Kendrickiana veitchi and Nipponoclava gigantea, but unlike $B$. vaginiferus and $F$. novaezelandiae, $P$. philippinensis has a fourth pallial aperture located just posterior to the ends of the saddle of papillae. LacazeDuthiers (1883) also described P. (as Aspergillum) dichotomum Chenu, 1843 (=P. philippinensis) as possessing a fourth pallial aperture, whereas $P$. (as Brechites) penis does not (Purchon 1956, 1960). The entire body of $P$. philippinensis is covered in periostracum, except for the saddle-shaped area of papillate mantle beneath the overlying calcareous concretion. In Figure 4 also the periostracum has been removed from the pedal disc to show the papillae on its outer surface.

\section{The organs of the mantle cavity}

The organs of the mantle cavity of Penicillus philippinensis are shown from the right lateral aspect in Figure 5. From the antero-ventral surface of the visceral mass arises a small round-ended foot that is aligned approximately with the gape of the pedal disc. The visceral mass is also pointed posteriorly and contains paired dorsal ovaries and ventral testes. The ctenidia are long, as in $P$. penis
(Purchon 1956), and extend into the apices of the siphons as in Foegia novaezelandiae (Morton 2004a). Each ctenidium comprises a complete inner demibranch and the ascending limb only of the outer demibranch. This is typical of all known, nonseptibranch anomalodesmatans (Morton 1981, 1985) and is of the Type E of Atkins (1936, 1937a). There are thus ciliary acceptance tracts in the ctenidial axes and in the ventral marginal food grooves of the inner demibranchs. The ctenidia are, however, very short dorso-ventrally and link up anteriorly with relatively large labial palps in a junction described by Stasek (1963) as Category III. All labial palps possess transverse ridges on their inner faces and thus effect sorting of any particles collected and transported to them by the ctenidia. The proximal oral grooves are long and the outer lip of the mouth overarches the inner.

\section{The siphons}

The siphons of Penicillus philippinensis are illustrated from the posterior aspect in Figure 6 . The exhalant siphon comprises a simple unornamented cone while the aperture of the inhalant siphon is fringed by eight small papillae. Surrounding the two siphons is a ring of fourteen papillae, eight around the exhalant and six around the inhalant. The periostracum extends up to the apices of the siphonal openings but does not cover them. As in Nipponoclava gigantea (Morton 2004c), but unlike other penicillids, including $P$. penis (Purchon 1956, 1960), the siphonal periostracum is not camouflaged by adhering sand grains and other debris.

The siphons are illustrated in transverse section in Figure 7A. The 14 siphonal nerves that connect up with the encircling siphonal papillae are shown, as is the general distribution of the siphon glands that characterise the siphonal apices of most

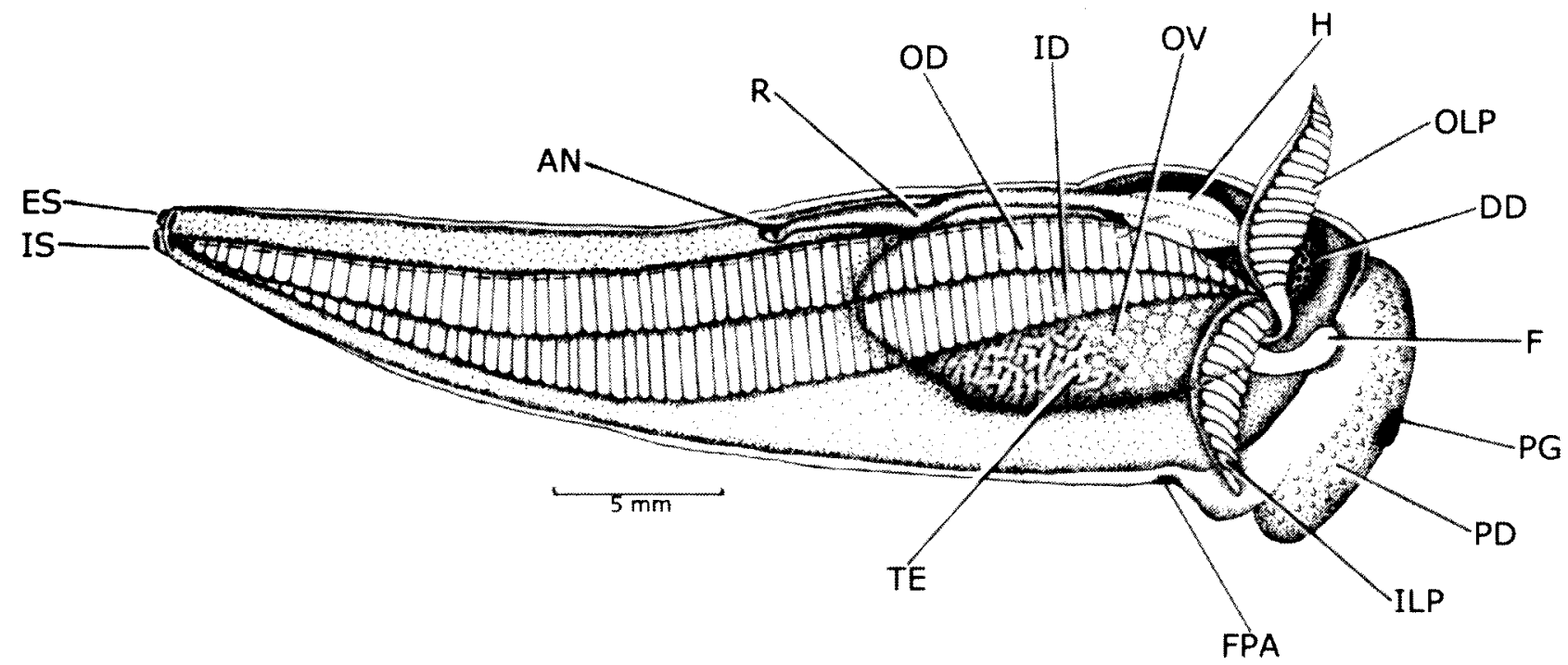

Figure 5 Penicillus philippinensis. The organs of the mantle cavity, as seen from the right side. For abbreviations see the Appendix. 


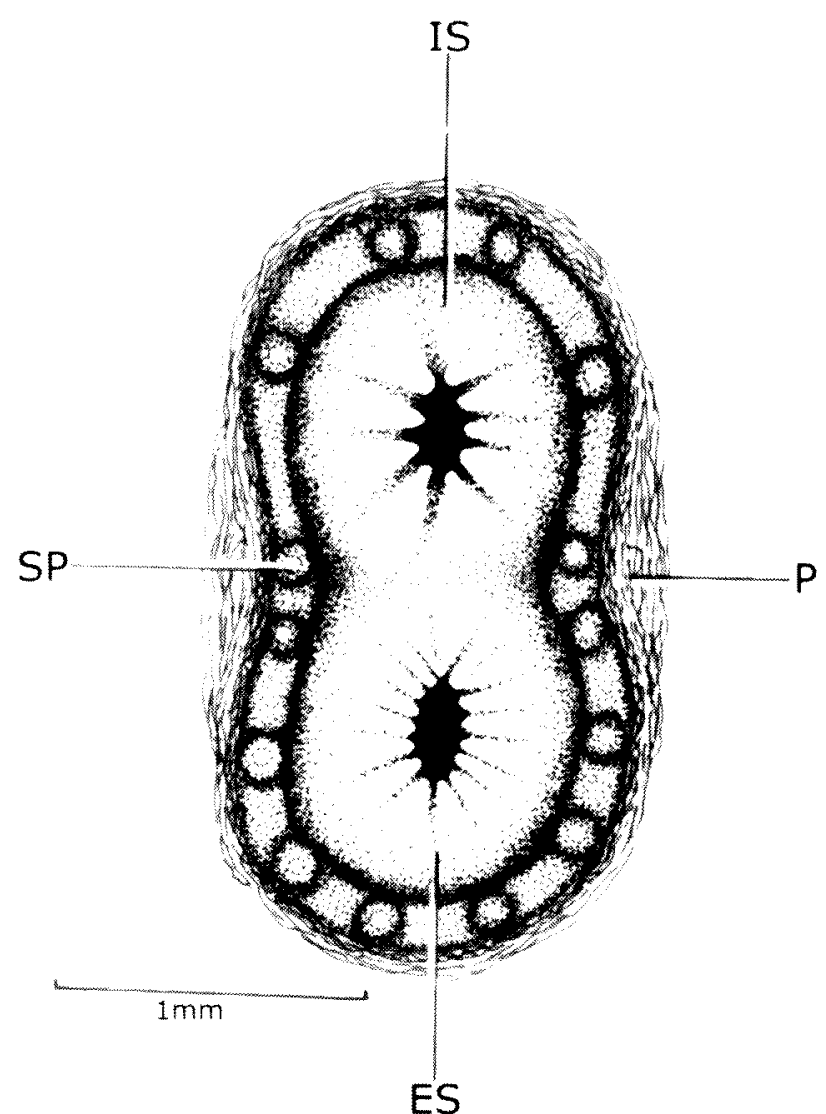

Figure 6 Penicillus philippinensis. The siphons as seen from the posterior aspect. For abbreviations see the Appendix. penicillids. Unlike other penicillids, but as in Nipponoclava gigantea (Morton 2004c), there are no radial mantle glands in the apices of the siphons. Such glands were first described by Prezant (1979b) for Lyonsia hyalina and were believed to produce a sticky secretion binding sand grains and other debris to the siphons and shell to camouflage them. The absence of such glands in both $P$. philippinensis and Nipponoclava gigantea (Morton 2004c) probably explains the absence of debris attached to the siphonal periostracum of these species. The siphonal wall is shown in greater detail in Figure 7B. Internal to the inner epithelium is a haemocoelomic area that also contains the red staining (in Masson's trichrome) siphonal glands, illustrated in greater detail for $N$. gigantea (Morton 2004c). The outer epithelium is connected to the body of the siphonal wall by bundles of transverse muscle fibres. Internal to this are twice repeated layers of circular and longitudinal muscles. Beneath the outer epithelium is another haemocoelomic area cross- connected to the internal muscle layers by bundles of transverse fibres. The two layers of longitudinal muscles in the siphonal walls are cross-connected by bundles of oblique muscles. The outer epithelium is covered by periostracum comprising two layers, that is, a thick inner layer which stains blue in Masson's trichrome and is therefore probably mucoid and a thinner $(\sim 2 \mu \mathrm{m})$ outer layer which stains red and is therefore proteinaceous.

B

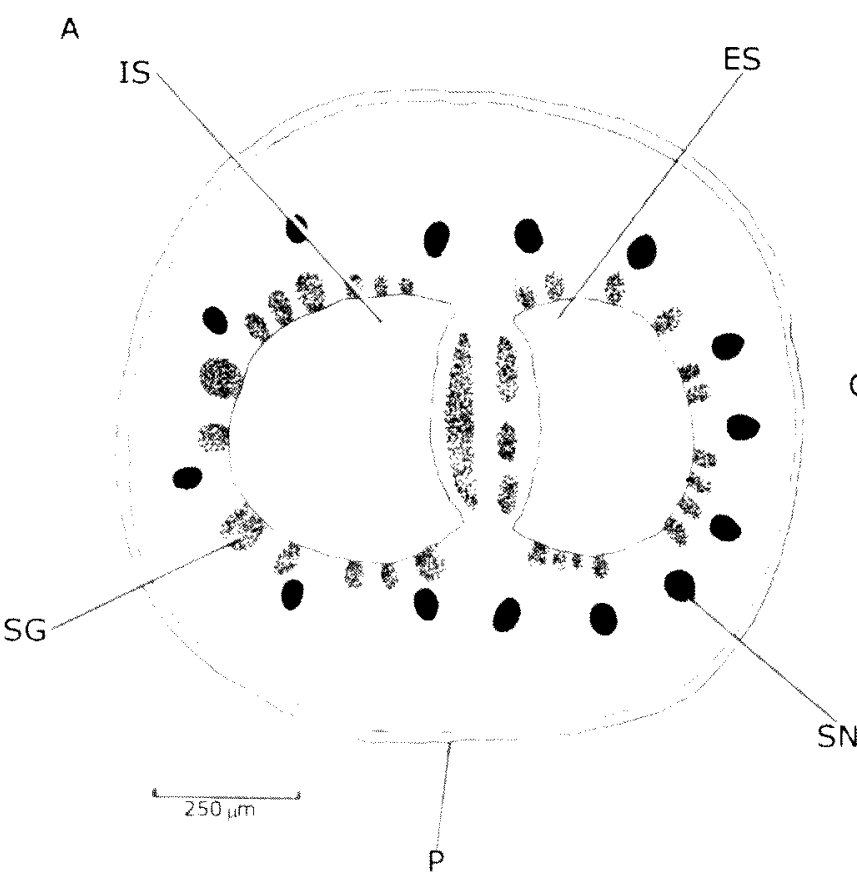

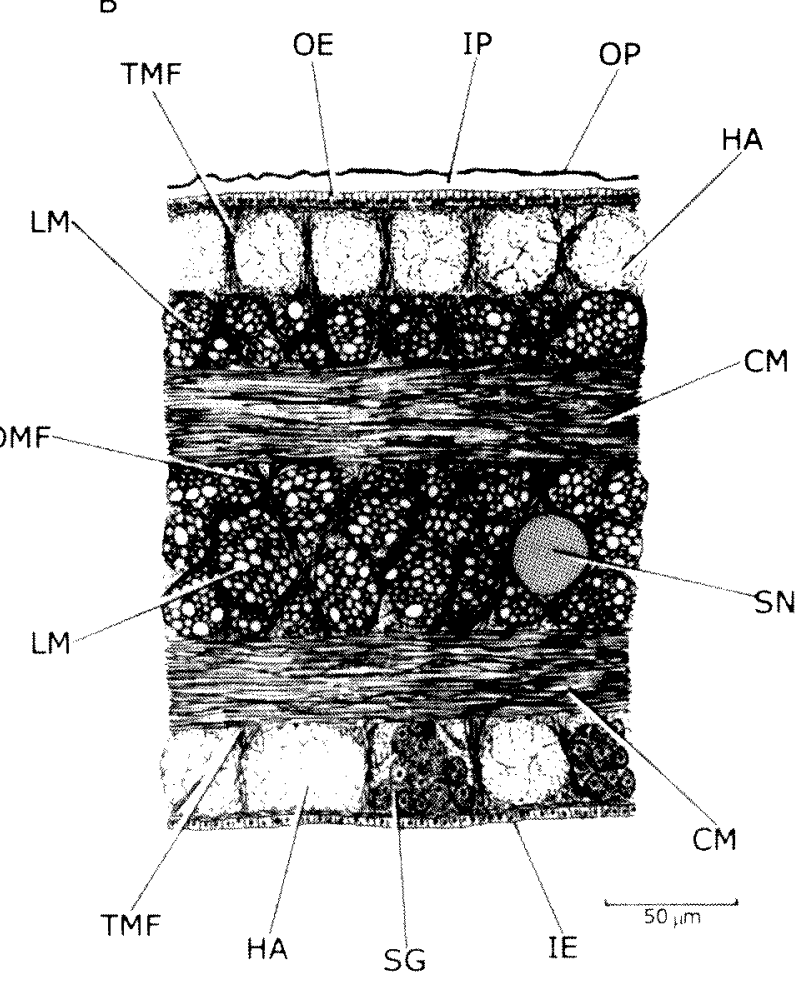

Figure 7 Penicillus philippinensis. A, A diagrammatic illustration of a transverse section through the siphons at their tips and $B$, a detail of a transverse section through the siphonal wall. For abbreviations see the Appendix. 


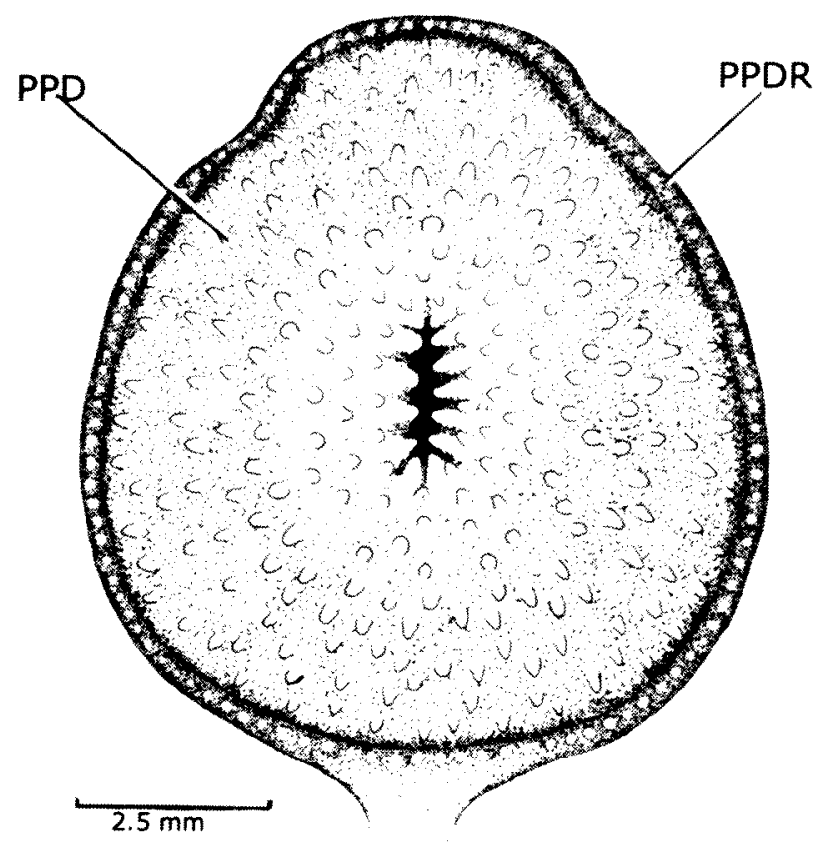

Figure 8 Penicillus philippinensis. The pedal disc as seen from the anterior aspect. For abbreviations see the Appendix.

The pedal disc

The highly muscular pedal disc of Penicillus philippinensis is illustrated from the posterior aspect in Figure 8. The periostracum covering it has been removed to show the epithelium of the disc dotted with small papillae. Similarly, the circumference of the disc is defined by a papillate, raised rim. In the centre of the disc is a dorsoventrally aligned pedal gape. In Foegia novaezelandiae, the periostracum covering the pedal disc is covered in an agglomeration of inorganic and organic debris and rod-shaped bacteria (Morton 2004a): this has not been observed in $P$. philippinensis.

\section{The ventral mantle margin}

The mid-ventral mantle margin of Penicillus philippinensis is illustrated in transverse section in Figure 9. Mantle fusion is extensive and involves inner and middle mantle folds and the inner surfaces only of the outer mantle folds, Type $C$ of Yonge (1982). Virtually the entire surface of the mantle is therefore covered in periostracum. The periostracum arises from left and right periostracal grooves, located just below the point of attachment of the pallial retractor muscles onto the tube. The ventral mantle margin largely comprises a haemocoel but there are additional bundles of longitudinal muscles that will assist in siphonal retraction.

\section{The papillate pallial saddle and musculature}

The structure of the pallial saddle in Penicillus philippinensis is illustrated in dorsal view in Figure 10. It abuts the pallial line and hence its pallial retractor muscles and the dorsal visceral mass posteriorly and the rim of the pedal disc anteriorly. It extends laterally, to the left and right, around the mantle (Figure 4). It is not covered in periostracum and, although covered in small papillae, is transparent enough to identify the fine strands of the vestigial anterior adductor muscle, also identified in $P$. penis (Purchon 1956, 1960). Two

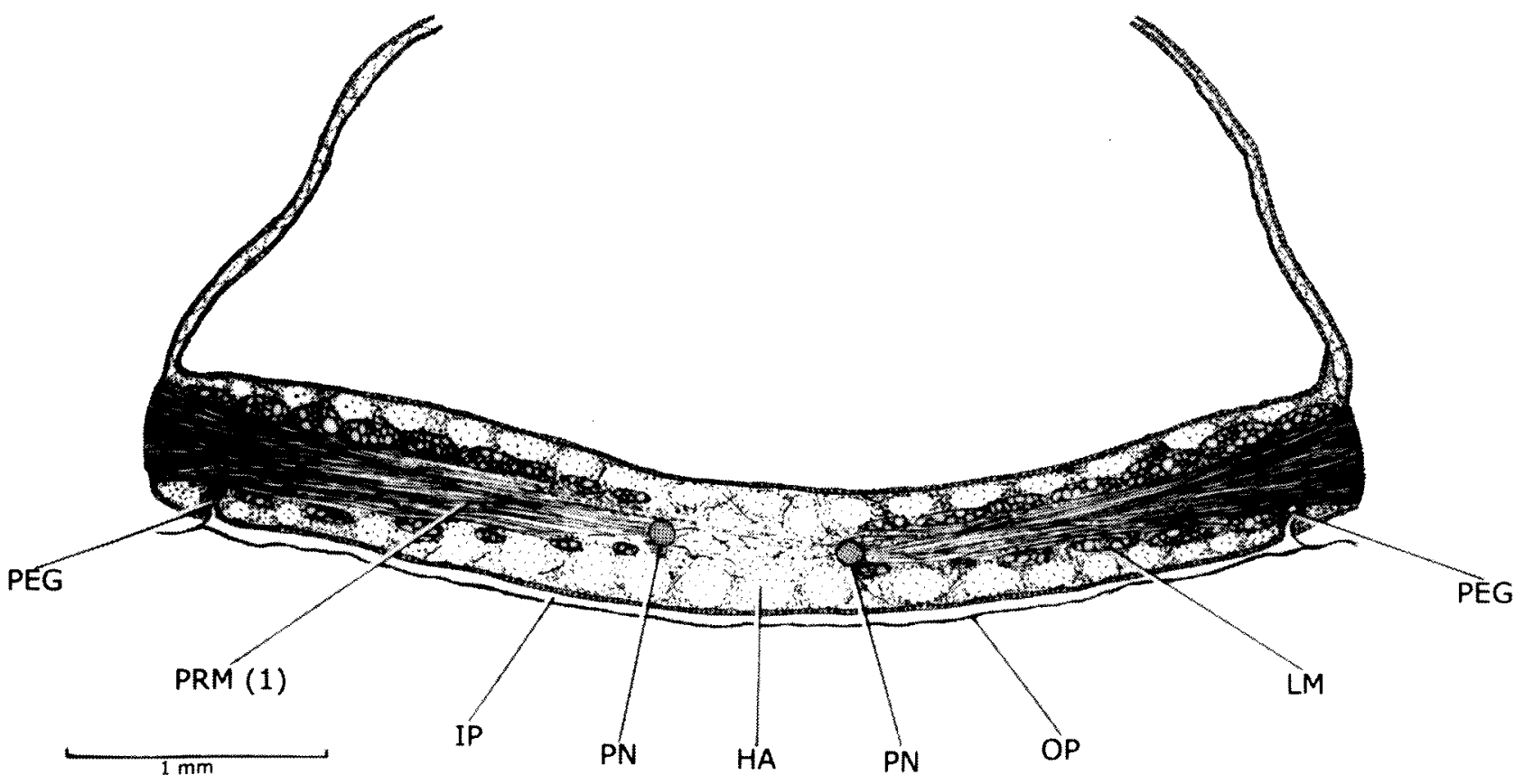

Figure 9 Penicillus philippinensis. A transverse section through the mid-ventral mantle margin. For abbreviations see the Appendix. 


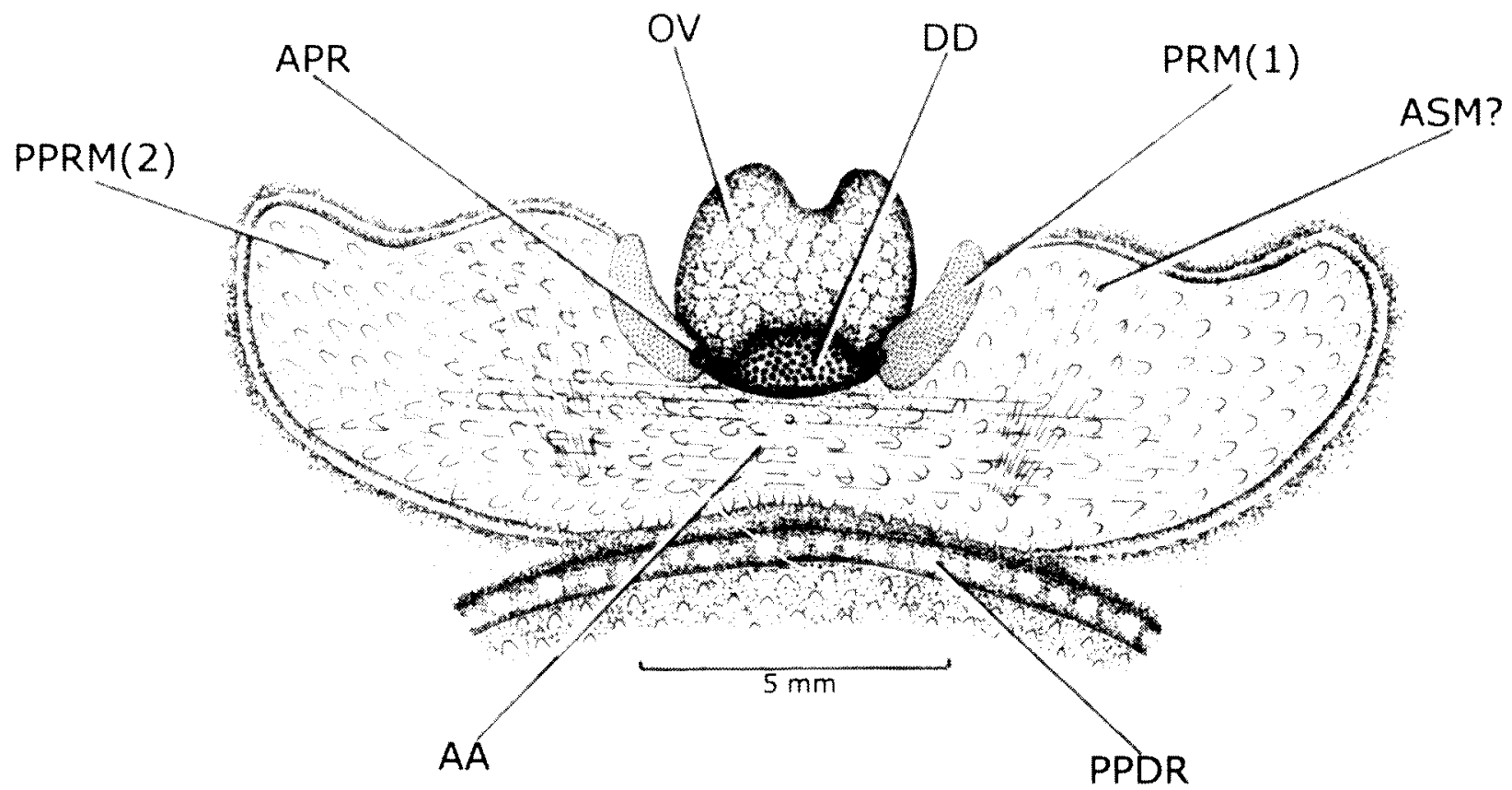

Figure 10 Penicillus philippinensis. The true pallial retractor muscles and saddle-shaped array of pallial papillae as seen from the dorsal aspect and somewhat spread out. For abbreviations see the Appendix.

small muscles, herein termed accessory suspensory muscles as they function like those of greater definability seen in Kendrickiana veitchi (Morton $2004 \mathrm{~b}$ ), serve to attach the antero-dorsal region of the visceral mass to the adventitious tube. Purchon $(1956,1960)$ did not identify such muscles in $P$. penis.

The mantle margin of Penicillus philippinensis at the pallial saddle is illustrated in transverse section in Figure 11. As with the mantle margin further posteriorly (Figure 9), mid ventrally there are large haemocoelomic spaces, (fewer) longitudinal muscle fibres and both left and right pallial retractor muscles. However, here, the lateral areas of the mantle are thickened and are traversed from the inner mantle epithelium to the outer by discrete muscle blocks interspersed by haemocoelomic spaces. These must be responsible for contraction of

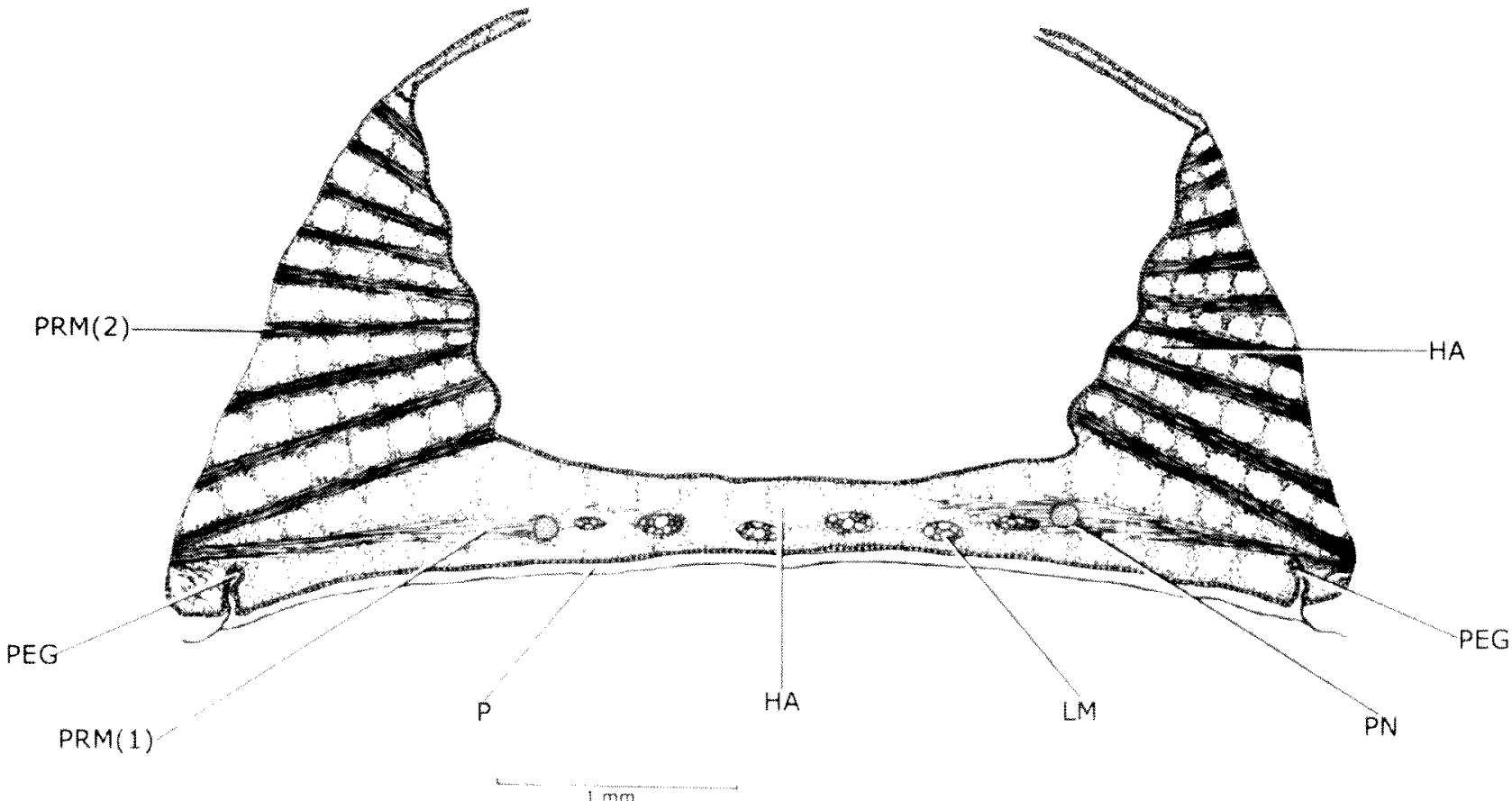

Figure 11 Penicillus philippinensis. A transverse section through the antero-yentral mantle margin showing the true pallial retractor muscles and the muscles of the saddle-shaped array of pallial papillae. For abbreviations see the Appendix. 

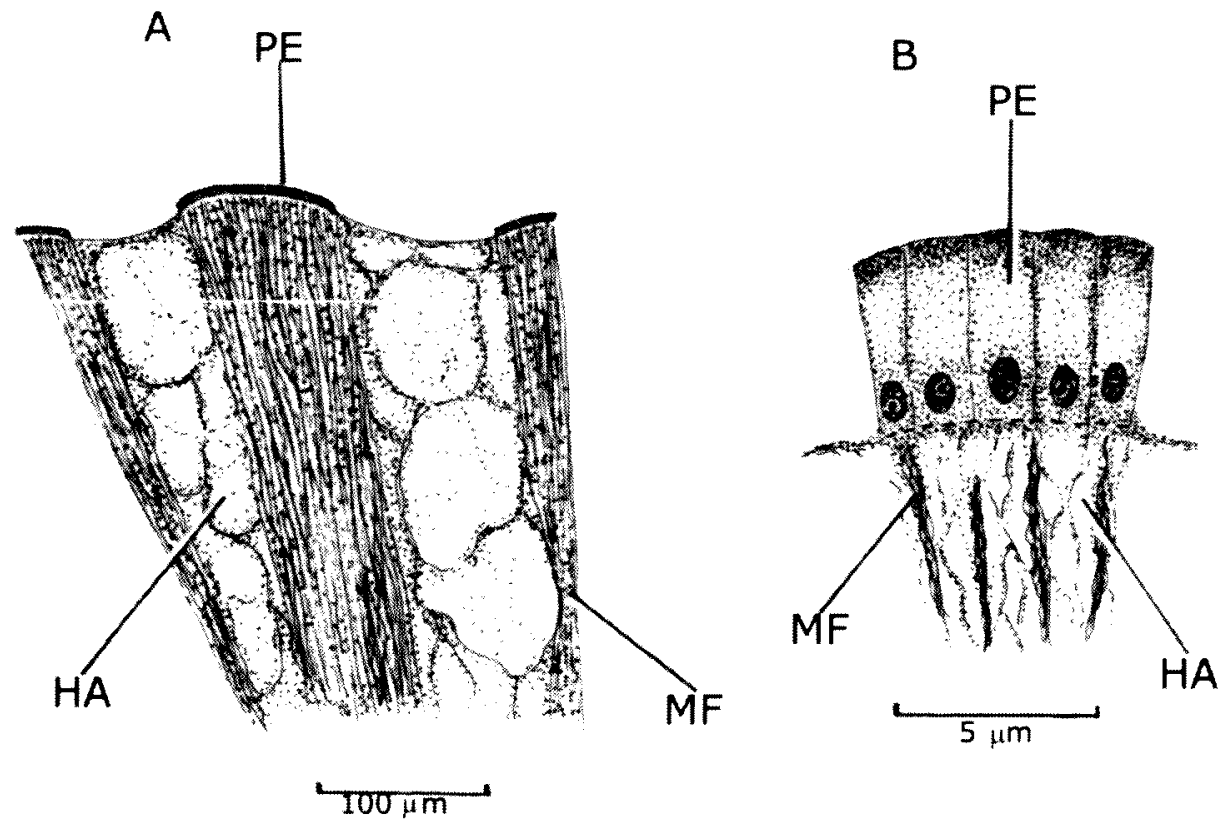

Figure 12 Penicillus philippinensis. Transverse sections through the points of attachment of the papillae of the saddleshaped array of pallial retractor muscles to the adventitious tube at two different levels of magnification. For abbreviations see the Appendix.

the mantle inwards and upwards, as in Kendrickiana veitchi (Morton 2004b).

Points of attachment of the pallial saddle papillae to the calcareous area of the adventitious tube of Penicillus philippinensis are shown in greater detail in Figure 12A. Each muscle unit, separated from its neighbours by haemocoelomic spaces, ends in a small swelling, identified as a small papillae, on the outer surface of the saddle. Closer inspection of the attachment point shows that the muscles are not attached directly to the tube but form a union with the basement membrane of a group of epithelial cells some $5 \mu \mathrm{m}$ tall (Figure 12B). This is unlike the situation seen in Kendrickiana veitchi where the much larger equivalent papillae are attached directly to the tube by papilla muscles (Morton 2004b)

The remnants of the true musculature of Penicillus philippinensis are illustrated in Figure 13 in a transverse section through the dorsal visceral mass. Above it is the delicate, vestigial anterior adductor muscle and flanking it are the paired remnants of the anterior pedal retractor muscles. Also seen in Figure 13 are antero-dorsally located

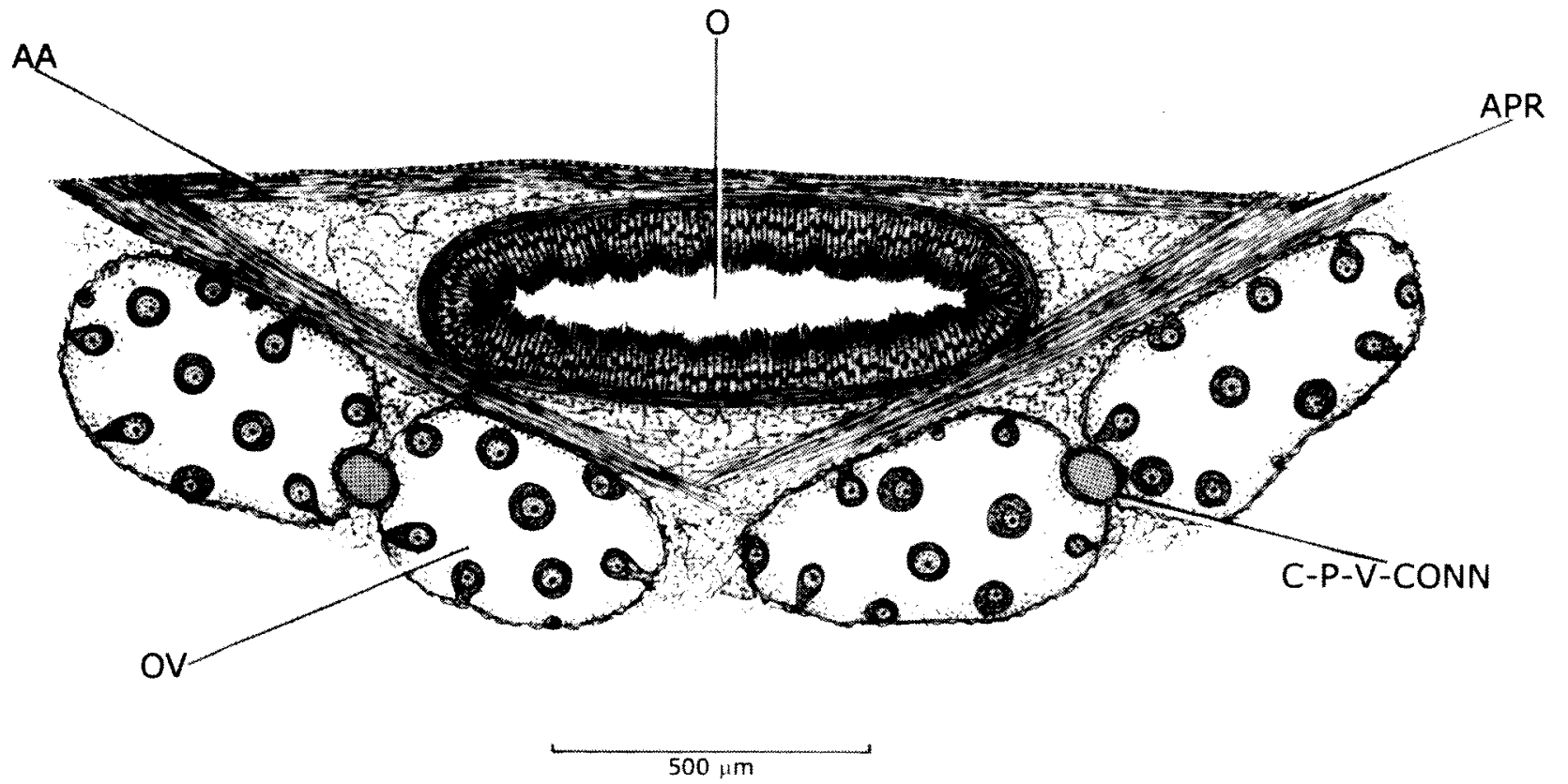

Figure 13 Penicillus philippinensis. A transverse section through the oesophagus also showing the vestigial anterior adductor and pedal retractor muscles. For abbreviations see the Appendix. 


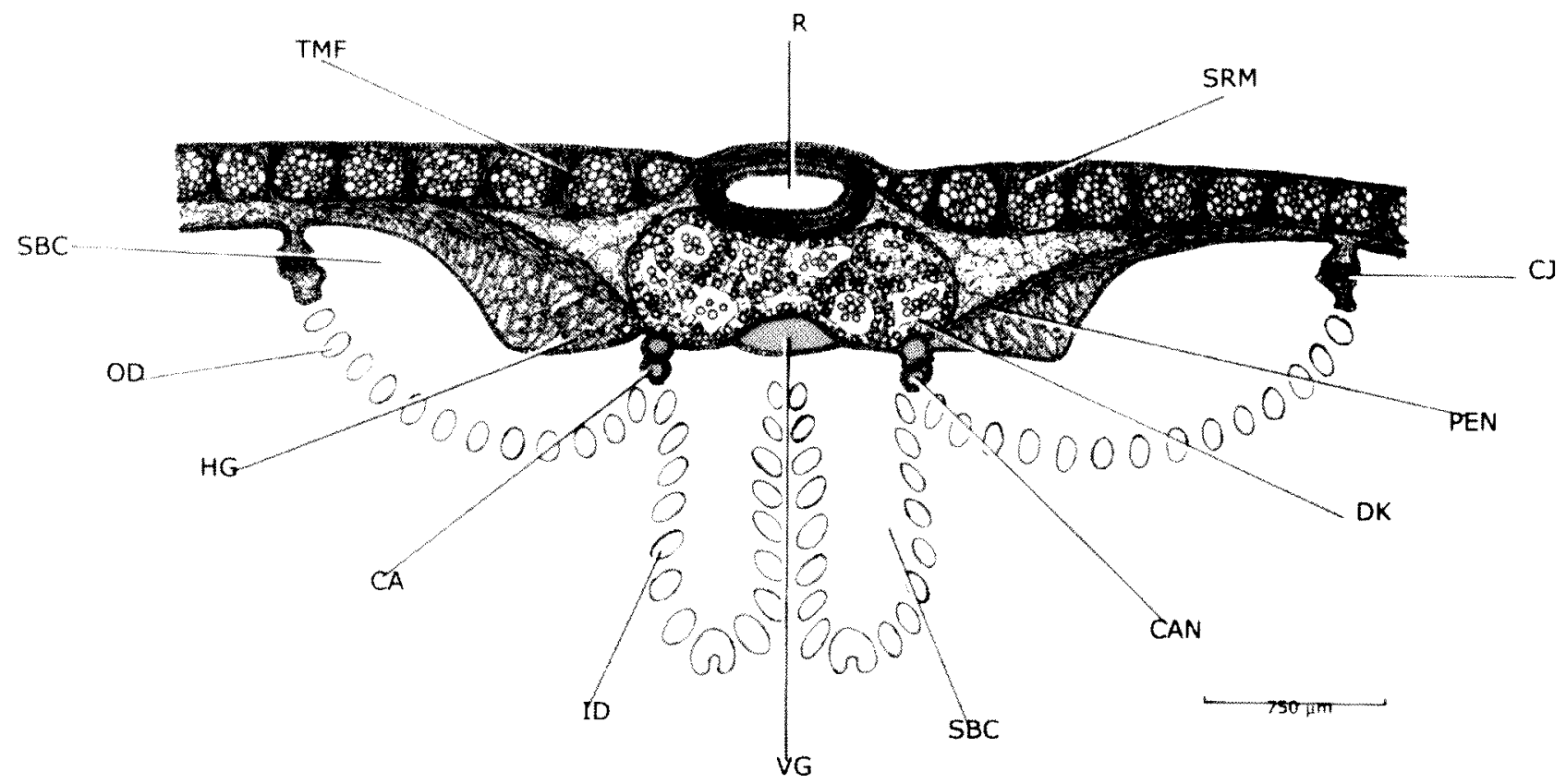

Figure 14 Penicillus philippinensis. A transverse section through the rectum, kidneys, hypobranchial glands and visceral ganglia. For abbreviations see the Appendix.

ovaries. The paired testes are located posteroventrally in the visceral mass.

The pericardium and kidneys

The pericardium of Penicillus philippinensis is illustrated in right lateral view in Figure 5 . The ventricle of the contained heart surrounds the rectum. The auricles lie above the supra-branchial chamber of the outer demibranch. In transverse section (Figure 14), the rectum comprises a simple tube that possesses a thick muscular coat. In the dorsal mantle, to the left and right of the rectum, are the dorsal elements of the longitudinal muscles of the siphonal retractors. Beneath the pericardium are the posterior elements of the kidneys. In this section, only the tubules of the distal limbs are present. The paired kidneys do, however, comprise paired ciliated proximal limbs that open into the supra-branchial chamber at renal apertures. The surrounding distal limbs comprise tubules made up of epithelial cells some $8 \mathrm{\mu m}$ tall and which are mostly vacuolated. Within some cells and densely occupying the tubule lumina are spherical kidney concretions approximately $10 \mu \mathrm{m}$ in diameter and which stain blue in Masson's trichrome but have a lighter core.

The supra-branchial chamber of the outer demibranch is lined dorsally by a hypobranchial gland typical of all penicillids and illustrated in detail for Nipponoclava gigantea by Morton (2004c). Beneath the posterior edges of the kidneys lie the visceral ganglia with nerves extending into the mantle and ctenidial axes. The outer demibranch attaches to the mantle at a cuticular junction like that described by Atkins (1937b).
The visceral ganglia

The visceral ganglia of Penicillus philippinensis are illustrated from beneath in Figure 15. They lie

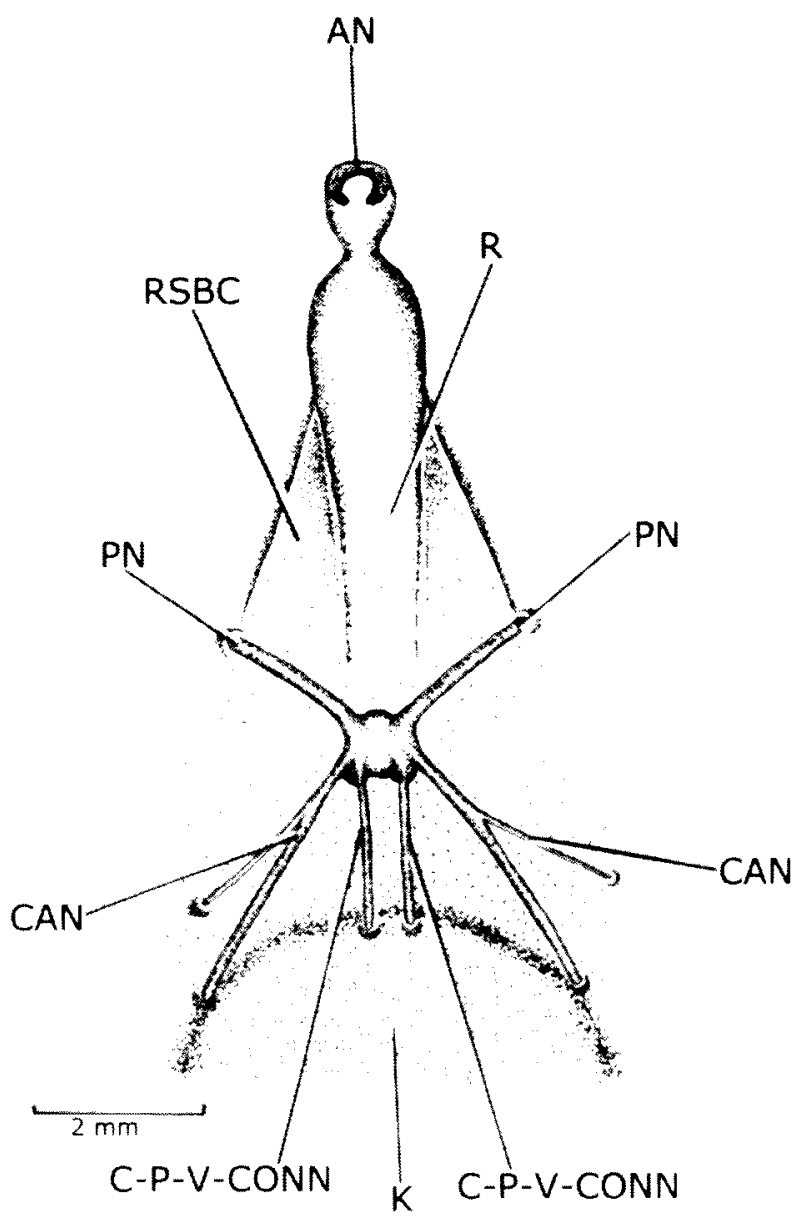

Figure 15 Penicillus philippinensis. A ventral view of the visceral ganglia and associated nerves. For abbreviations see the Appendix. 
between the kidneys anteriorly and rectum, the latter extending into the supra-branchial chamber posteriorly. The paired ganglia are connected to the cerebro-pleural ganglia anteriorly by cerebropleural visceral connectives that pass anteriorly into the kidneys. From the posterior ends of the ganglia arise the posterior pallial nerves that posteriorly divide and extend into the siphons. From the anterior lateral edges of the ganglia arise nerves that divide into two components and make connection with the ctenidia at the ctenidial axes.

\section{The statocysts}

The statocysts of Penicillus philippinensis are located in close proximity to the dorso-lateral edges of the pedal ganglia (Figure 16). But one is

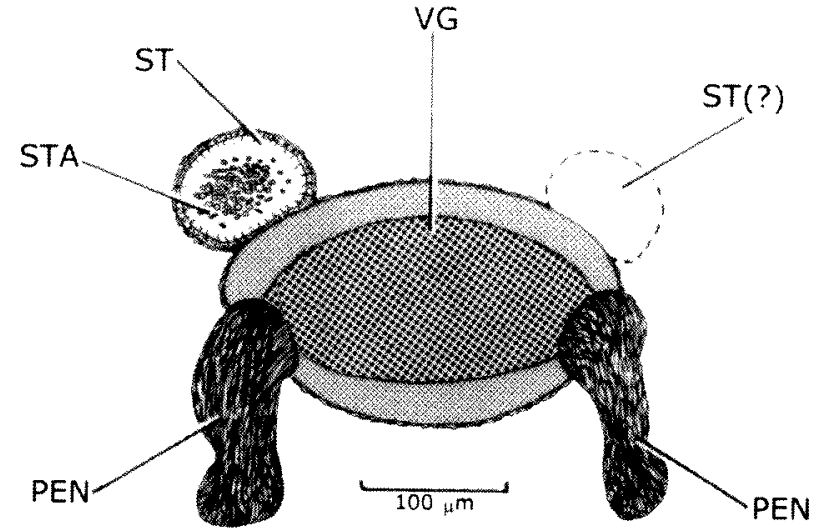

Figure 16 Penicillus philippinensis. A transverse section through the right statocyst and pedal ganglia. For abbreviations see the Appendix.
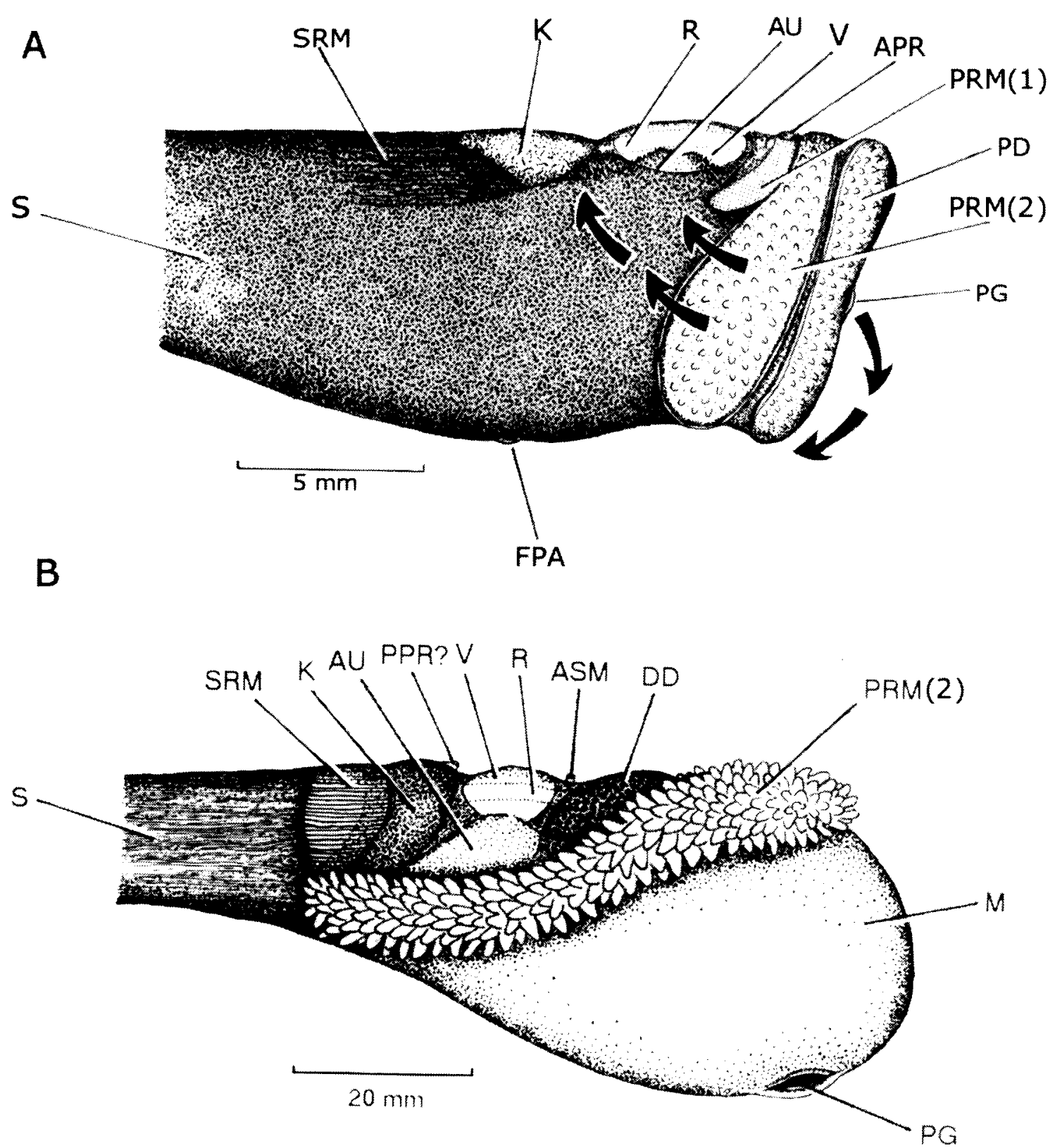

Figure 17 Penicillus philippinensis. A, The anterior end of an individual showing how the postero-dorsal movement of the papillate pallial retractor muscles and pedal disc would essentially recreate the situation seen in $B$ Kendrickiana veitchi (redrawn after Morton 2004a). For abbreviations see the Appendix. 
illustrated because only one in ten sections of the specimen was saved thus losing the second statocyst. The statocysts are Type $B_{3}$ of Morton (1985b) as are those of all other penicillids described to date. Each statocyst thus possesses a large number of small crystalline statoconia of about equal size and there is not one dominant statolith as in other statocyst types (Morton 1985b).

\section{DISCUSSION}

Penicillus philippinensis can be separated from $P$. penis on the basis of the form of the adventitious tube which is curved in the former and straight in the latter, and by the presence of anterior pedal retractor muscles and a fourth pallial aperture (Purchon 1956, 1960; this study). Of all known penicillids, however, $P$. philippinensis (Figure 17A) is structurally most similar to Kendrickiana veitchi (Morton 2004b) (Figure 17B). This similarity relates to the occurrence in both, respectively, of a saddleor horseshoe-shaped array of muscular papillae, that connects each animal to its adventitious tube dorso-laterally. No other clavagelloid possesses such an array of muscular pallial papillae. The situation in $K$. veitchi seems to have evolved from an ancestral condition similar to that in $P$. philippinensis by the rotation dorsally of the papillate area of mantle and the movement of the pedal gape to a more antero-ventral, as opposed to a more anterior, position (Figure 17). This scenario may also account for the radial symmetry of the watering pot of $P$. philippinensis and the asymmetrical one of $K$. veitchi. There are, moreover, other differences between the two. In many ways the simple, tiny papillae of $P$. philippinensis foreshadow the situation seen in $K$. veitchi. That is, the papillae of the latter are large and have a deep muscular attachment within pits in the adventitious tube, whereas in the former they are slightly attached, via the intermediary of an epithelium, to the calcareous concretion covering the interior surface of the tube beneath and anterior to the positions of the true shell valves. Kendrickiana veitchi also possesses a distinct pair of accessory suspensory muscles, attaching the visceral mass dorsally to the adventitious tube. There is a similar but much smaller, less distinct, pair of such muscles in $P$. philippinensis. Conversely, $P$. philippinensis possesses an, albeit small, pallial line on the tube (with pallial retractor muscles), whereas $K$. veitchi does not. Purchon (1956, 1960) described neither dorsal saddle papillae nor suspensory muscles for $P$. penis.

This study of Penicillus philippinensis completes a personal series of papers on the structure of the adventitious tubes and anatomical characteristics of representatives of the known genera of the Penicillidae, that is, Brechites vaginiferus,
Humphreyia strangei, Foegia novaezelandiae, Kendrickiana veitchi and Nipponoclava gigantea (Morton 1984a, 2002a, b, 2004a, b, c). Such characteristics are compared and summarized in Table 1. Morton (2006) has published a similar table for representatives of the extant genera of the Clavagellidae, that is, Dacosta australis (Sowerby, 1829), Bryopa aligamenta (Morton, 2005), Dianadema multangularis and Stirpulina ramosa Dunker, 1882. All representatives of the Penicillidae are characterized by having both shell valves incorporated into the structure of the adventitious tube, unlike representatives of the Clavagellidae where only the left valve is - the right being free within the crypt (Dacosta, Bryopa) or tube (Dianadema, Stirpulina). Humphreyia strangei is easily distinguished from all other penicillids by being cemented epibenthically. Representatives of all other genera are endobenthic and occupy vertically oriented adventitious tubes. Representatives of the five endobenthic genera are separable in terms of the details of the tube structure, for example whether the shell valves are clearly visible (Brechites, Penicillus, Nipponoclava) or covered by concretions (Foegia, Kendrickiana). They are also separable in terms of anatomical details. For example, although all have lost their posterior adductor muscles, a vestigial anterior muscle is present in both Penicillus and Nipponoclava. Similarly, remnant anterior pedal retractor muscles are present only in Brechites, Penicillus and Nipponoclava whereas remnant posterior pedal retractor muscles are present only in Humphreyia, Kendrickiana and Nipponoclava facilitating the development in these genera only of pericardial proprioreceptors. Similarly a fourth pallial aperture is present only in the juvenile of Humphreyia and in Nipponoclava, while only Penicillus and Nipponoclava do not possess radial mantle glands at the siphonal tips.

Notwithstanding such differences of detail, all penicillids are united in the possession of Type $C$ pallial fusions (Yonge 1982), Type E ctenidia (Atkins 1936, 1937a), a Type 3 ctenidial labial palp junction (Stasek 1963) and statocysts of Type $B_{3}$ (Morton 1985b). Such characters are also common to representatives of the Clavagellidae (Morton 2006) suggesting a common ancestry, albeit with radiation of the two families in the Mesozoic (Clavagellidae) and Cenozoic (Penicillidae) (Morton 2006).

Gray (1858b), Lamy 1923, Smith (1978) and Morton (1984a, 2002a), among others, have speculated upon the formation of the clavagelloid adventitious tube. All authors agree that the structure is produced but once although it may be added to posteriorly to effect growth and repair. Harper and Morton (2004) described how in Brechites vaginiferus the sequential secretion of 
Table 1 A comparison of shell, adventitious tube and internal anatomical characters of Brechites and its allies (Penicilloidea: Penicillidae)

\begin{tabular}{|c|c|c|c|c|c|c|}
\hline Character & Brechites & Humphreyia & Penicillus & Foegia & Kendrickiana & Nipponoclava \\
\hline Shell & $\begin{array}{l}\text { Juvenile } \\
\text { + saddle }\end{array}$ & $\begin{array}{l}\text { Juvenile } \\
\text { + saddle }\end{array}$ & $\begin{array}{l}\text { Juvenile } \\
\text { + saddle }\end{array}$ & $\begin{array}{l}\text { Juvenile } \\
\text { + saddle }\end{array}$ & $\begin{array}{l}\text { Juvenile } \\
\text { + saddle }\end{array}$ & $\begin{array}{l}\text { Post-juvenile } \\
\text { + saddle }\end{array}$ \\
\hline Shell & $\begin{array}{l}\text { Both valves } \\
\text { united with } \\
\text { adventitious } \\
\text { tube }\end{array}$ & $\begin{array}{l}\text { Both valves } \\
\text { united with } \\
\text { adventitious } \\
\text { tube }\end{array}$ & $\begin{array}{l}\text { Both valves } \\
\text { united with } \\
\text { adventitious } \\
\text { tube }\end{array}$ & $\begin{array}{l}\text { Both valves } \\
\text { united with } \\
\text { adventitious } \\
\text { tube }\end{array}$ & $\begin{array}{l}\text { Both valves } \\
\text { united with } \\
\text { adventitious } \\
\text { tube }\end{array}$ & $\begin{array}{l}\text { Both valves } \\
\text { united with } \\
\text { adventitious } \\
\text { tube }\end{array}$ \\
\hline Ligament & External & External & External & External & External & External \\
\hline Lithodesma & Unknown & Present & Unknown & Unknown & Unknown & Unknown \\
\hline Periostracum & Two layers & Two layers & Two layers & Two layers & Two layers & Two layers \\
\hline Shell microstructure & $\begin{array}{l}\text { Prismatic } \\
\text { outer layer } \\
\text { Inner sheet } \\
\text { nacre }\end{array}$ & $\begin{array}{l}\text { Prismatic } \\
\text { outer layer } \\
\text { Inner sheet } \\
\text { nacre }\end{array}$ & $\begin{array}{l}\text { Prismatic } \\
\text { outer layer } \\
\text { Inner sheet } \\
\text { nacre }\end{array}$ & $\begin{array}{l}\text { Prismatic } \\
\text { outer layer } \\
\text { Inner sheet } \\
\text { nacre }\end{array}$ & $\begin{array}{l}\text { Prismatic } \\
\text { outer layer } \\
\text { Inner sheet } \\
\text { nacre }\end{array}$ & $\begin{array}{l}\text { Prismatic } \\
\text { outer layer } \\
\text { Inner sheet } \\
\text { nacre }\end{array}$ \\
\hline Adventitious tube & Present & Present & Present & Present & Present & Present \\
\hline Adventitious tube & $\begin{array}{l}\text { Free / } \\
\text { cemented }\end{array}$ & Cemented & Free & Free & Free & Free \\
\hline Watering pot & Present & Present & Present & Present & Present & Present \\
\hline Anterior tubules & Present & $\begin{array}{l}\text { Present } \\
\text { but occluded }\end{array}$ & Present & Present & Present & Present \\
\hline Juvenile & $\begin{array}{l}\text { Juvenile } \\
\text { metamorphosis }\end{array}$ & $\begin{array}{l}\text { Juvenile } \\
\text { metamorphosis }\end{array}$ & $\begin{array}{l}\text { Juvenile } \\
\text { metamorphosis }\end{array}$ & $\begin{array}{l}\text { Juvenile } \\
\text { metamorphosis }\end{array}$ & $\begin{array}{l}\text { Juvenile } \\
\text { metamorphosis }\end{array}$ & $\begin{array}{l}\text { Juvenile } \\
\text { metamorphosis }\end{array}$ \\
\hline $\begin{array}{l}\text { Anterior adductor } \\
\text { muscles }\end{array}$ & Unknown & Present & Unknown & Unknown & Unknown & Present \\
\hline $\begin{array}{l}\text { Posterior adductor } \\
\text { muscle }\end{array}$ & Unknown & Present & Unknown & Unknown & Unknown & Present \\
\hline $\begin{array}{l}\text { Anterior pedal } \\
\text { retractor muscles }\end{array}$ & Unknown & Absent & Unknown & Unknown & Unknown & Present \\
\hline $\begin{array}{l}\text { Posterior pedal } \\
\text { retractor muscles }\end{array}$ & Unknown & Absent & Unknown & Unknown & Unknown & Present \\
\hline Pallial sinus & Unknown & Absent & & Unknown & & Present \\
\hline \multicolumn{7}{|l|}{ Adult } \\
\hline $\begin{array}{l}\text { Anterior adductor } \\
\text { muscle }\end{array}$ & Absent & Absent & Present & Absent & Absent & Present \\
\hline $\begin{array}{l}\text { Posterior adductor } \\
\text { muscle }\end{array}$ & Absent & Absent & Absent & Absent & Absent & Absent \\
\hline $\begin{array}{l}\text { Anterior pedal } \\
\text { retractor muscles }\end{array}$ & Present & Absent & Present & Absent & Absent & Present \\
\hline $\begin{array}{l}\text { Posterior pedal } \\
\text { retractor muscles }\end{array}$ & Absent & Present & Absent & Absent & Present & Present \\
\hline Pedal disc & Present & Present & Present & Present & Absent & Present \\
\hline $\begin{array}{l}\text { Pericardial } \\
\text { proprioreceptors }\end{array}$ & Absent & Present & Absent & Absent & Present & Present \\
\hline Rectum & $\begin{array}{l}\text { Passes } \\
\text { above kidneys }\end{array}$ & $\begin{array}{l}\text { Passes } \\
\text { above kidneys }\end{array}$ & $\begin{array}{l}\text { Passes } \\
\text { above kidneys }\end{array}$ & $\begin{array}{l}\text { Passes } \\
\text { above kidneys }\end{array}$ & $\begin{array}{l}\text { Passes } \\
\text { above kidneys }\end{array}$ & $\begin{array}{l}\text { Passes } \\
\text { above kidneys }\end{array}$ \\
\hline Suspensory muscles & Absent & Absent & Present & Absent & Present & Absent \\
\hline U-shaped papillae & Absent & Absent & Present & Absent & Present & Absent \\
\hline Ctenidial ciliation & Type E & Type E & Type E & Type E & Type E & Type E \\
\hline $\begin{array}{l}\text { Ctenidial/labial } \\
\text { palp junction }\end{array}$ & Category 3 & Category 3 & Category 3 & Category 3 & Category 3 & Category C \\
\hline Pallial fusion & Type C & Type C & Type C & Type C & Type C & Type C \\
\hline $\begin{array}{l}\text { Fourth pallial } \\
\text { aperture }\end{array}$ & Present & $\begin{array}{l}\text { Present (only } \\
\text { in the juvenile) }\end{array}$ & Present & Present & Absent & Present \\
\hline Pedal gape & Present & $\begin{array}{l}\text { Partially } \\
\text { occluded }\end{array}$ & Present & Present & Present & Present \\
\hline Pedal disc glands & Present & Absent & Absent & Absent & Absent & Present \\
\hline Radial mantle glands & Present & Present & Absent & Present & Present & Absent \\
\hline $\begin{array}{l}\text { Siphonal sense } \\
\text { organs }\end{array}$ & Present & Present & Absent & Absent & Absent & Present \\
\hline Statocysts & Type $B_{3}$ & Type $B_{3}$ & Type $B_{3}$ & Unknown & Type $B_{3}$ & Type $B_{3}$ \\
\hline
\end{tabular}


periostracum, calcium carbonate and another layer of periostracum form the adventitious tube against the template of the burrow wall. The tube of Penicillus philippinensis is probably secreted in the same manner and, like all other penicillids, is probably produced but once.

Savazzi (1982) has described the general adaptations to life in a clavagelloid adventitious tube. The function of the tube has also been speculated upon. Purchon $(1956,1960)$ thought that water was pumped out of the watering pot into the sediment to liquefy the sediments and thereby effect reburial following disinterment. Savazzi (1999) inferred an ability to rebury on the basis of a reconstruction of the growth process of anomalous individuals of Brechites. Notwithstanding, Morton (2002a) showed that $B$. vaginiferus could not rebury and that interstitial water was pumped into the mantle cavity via the watering pot. Such an activity may have a number of functions, as described for Foegia novaezelandiae by Morton (2004a). One is to effect siphonal extension, following their withdrawal, by the hydraulic forces generated inside the mantle cavity and via pallial haemocoels pumping blood into the siphonal walls. Morton (2004a) further suggested for $F$. novaezelandiae that the tube also fulfils other functions of the true shell. That is, it functions as an exoskeleton which acts antagonistically to the hydraulically-generated forces in the mantle and body to effect the movement into and out of the mantle cavity of water from both the sea above and the interstitial spaces at the end of the burrow. The same structures and the forces they collectively engender essentially act to maintain the body in a state of optimal tonus.

Penicillus philippinensis and Kendrickiana veitchi are different from all other known penicillids, for example, Brechites vaginiferus, Foegia novaezelandiae, Nipponoclava gigantea (Morton 2002a, 2004a, b) and P. penis (Purchon $1956,1960)$ in the possession by the former two species of the saddle- or horseshoe-shaped array of muscular mantle papillae. This can be considered to represent a neomorph, that is, a secondarily derived structure replacing the pumping function of either the lost ( $K$. veitchi) or vestigial ( $P$. philippinensis) adductor and pallial retractor muscles but further serving to attach the animal to its tube and no longer the shell valves. As such, the papillae do not serve to close the shell valves, since these structures are tiny and immovably fused into the fabric of the adventitious tube, but re-create another function, that is, to generate the forces which effect the exchange of mantle fluids with the water column above and interstitial waters in the burrow below. How this is achieved has been illustrated and described for $K$. veitchi by Morton (2004b). It is suggested here that the same forces are generated by the saddle-shaped array of pallial papillae seen in $P$. philippinensis.

The siphons of Kendrickiana veitchi are poorly muscularised and cannot be contracted deeply into the adventitious tube (Morton 2004b) unlike in Brechites vaginiferus, Foegia novaezelandiae and Nipponoclava gigantea (Morton 2002a; 2004a, c). Strangely, the siphons of Penicillus philippinensis are well muscularised but the two specimens studied were not retracted deeply into their tubes. This species may be anatomically and functionally intermediate between $B$. vaginiferus and $F$. novaezelandiae, both of which exchange fluids in the mantle cavity using a pedal disc (a structure which $P$. philippinensis also possesses), and the muscularised mantle papillae of $K$. veitchi with no pedal disc. In these two groups of species, therefore, there are two quite different 'pumps' that create the hydraulic forces in the mantle cavity necessary to effect siphonal extension, the exchange of fluids between the supernatant water above and that of the burrow, respiration, the collection of particulate food and the discharge of pseudofaeces and faeces.

The pressures generated in the mantle cavity by contraction of the muscular mantle papillae (or pedal disc) must act, in turn, on the haemocoelomic blood vascular system to achieve movements of, for example, the foot but, especially, the siphons. In the case of Penicillus philippinensis and Kendrickana veitchi, the blood vessels and pallial haemocoels are huge in comparison with those of other penicillids, for example, Brechites vaginiferus, Foegia novaezelandiae and Nipponoclava gigantea (Morton 2002a, 2004a, b).

In many other respects Penicillus philippinensis is a typical penicillid, for example, with regard to the presence of a distinct pair of pallial retractor muscles attached to a pallial line on the tube, as in Brechites vaginiferus, Foegia novaezelandiae, Kendrickiana veitchi and Nipponoclava gigantea (Morton 2002a, 2004a, b, c) and to the structures of the mantle cavity, that is, the siphons, ctenidia and labial palps. Commensurate upon the earliest loss of the adductor and pedal retractor muscles with the adoption of a tube-dwelling mode of life, however, natural selection has resulted in the evolution of a new 'adductor muscle' system, that is, a heavily muscularised pedal disc pump. This structure characterizes many representatives of the endobenthic Penicillidae, for example, $B$. vaginiferus and $F$. novaezelandiae, and even the epibenthic cemented Humphreyia strangei (Morton 2002b). Possibly because of some inherent inefficiency in this system, however, natural selection has acted further to, essentially, re-create a yet more elaborate replacement for the lost adductor muscle system, that is, the horseshoeshaped array of muscular mantle papillae in $K$. veitchi. $P$. philippinensis seems, in the possession 
of a pallial line and functional pallial retractor muscles, a pedal disc but also a saddle-shaped array of muscular mantle papillae, to be representative of an intermediate state between these two kinds of pumps, thereby giving us an invaluable insight into how the unique muscular system of $K$. veitchi may have evolved.

\section{ACKNOWLEDGEMENTS}

This research was undertaken during the tenure of a Research Associateship awarded by the Western Australian Museum, Perth, Western Australia. I am grateful to the Director and staff of the Western Australian Museum for the provision of facilities. Ms S. M. Slack-Smith is also thanked for assistance in accessing the collections of modern Mollusca at the museum. I am particularly grateful to Dr A. Baldinger of the Museum of Comparative Zoology, The Agassiz Museum, Harvard University, for sending and allowing me to dissect and section the two specimens of Penicillus philippinensis herein reported upon. Finally, I would like to thank Dr J. D. Taylor (The Natural History Museum, London) for reading and critically commenting on the first draft of the manuscript of this paper.

\section{REFERENCES}

Aller, R.C. (1974). Prefabrication of shell ornamentation in the bivalve Laternula. Lethaia 7: 43-56

Appukuttan, K.K. (1974). Rediscovery of Clavagella (Bryopa) lata Bivalvia) from the Gulf of Mannar, Southeast coast of India. Journal of the Malacological Society of Australia 3: 19-24.

Atkins, D. (1936). On the ciliary mechanisms and interrelationships of lamellibranchs. Quarterly Journal of Microscopical Science 79: 181-308.

Atkins, D. (1937a). On the ciliary mechanisms and interrelationships of lamellibranchs. Part III. Types of lamellibranch gills and their food currents. Quarterly Journal of Microscopical Science 79: 375-421.

Atkins, D. (1937b). On the ciliary mechanisms and interrelationships of lamellibranchs. Part IV. Cuticular fusion with special reference to the fourth pallial aperture in certain lamellibranchs. Quarterly Journal of Microscopical Science 79: 423-445.

Bruguière, M. (1789). Encyclopedie Mèthodique; Histoire Naturelle des Vers, Vol.1 (XV): genus 33, 126-130. Pankouche, Paris.

Carter, J.G. and Aller, R.C. (1975). Calcification of the bivalve periostracum. Lethaia 8: 315-320.

Chenu, M. (1843). Aspergillum, Arrosior. Illustrations de Conchyliologie 1: 1-4, pl. 1-4.

Dharma, B. (1992). Indonesian Shells. Vol. 2. Hemmen, Wiesbaden.

Dreyer, H., Steiner, G. and Harper, E.M. (2003). Molecular phylogeny of Anomalodesmata (Mollusca: Bivalvia) inferred from 185 rRNA sequences.
Zoological Journal of the Linnean Society 139: 229246

Gray, J.E. (1847). A list of the genera of Recent Mollusca, their synonyms and types. Proceedings of the Zoological Society of London 15: 129-219.

Gray, J.E. (1858a). On the families of Aspergillidae, Gastrochaenidae and Humphreyiadae. Proceedings of the Zoological Society of London 26: 307-318.

Gray, J.E. (1858b). On the development of the shell and tube in Aspergillum. Annals and Magazine of Natural History 1: 423-426.

Harper, E.M. and Morton, B. (2004). Tube construction in the watering pot shell Brechites vaginiferus (Bivalvia; Anomalodesmata; Clavagelloidea). Acta Zoologica 85: 149-161.

Harper, E.M., Hide, E.A. and Morton, B. (2000). Relationships between the extant Anomalodesmata: a cladistic test. In E.M. Harper, J.A. Crame and J.D. Taylor (eds), Geological Society, London, Special Publications 177: 129-143.

Keen, M. and Smith, L.A. (1969). Superfamily Clavagellacea d'Orbigny, 1844. In R.C. Moore, (ed), Treatise on Invertebrate Paleontology, Part N, Vol. 2: Mollusca 6, Bivalvia. Lawrence, Kansas: Geological Society of America and University of Kansas Press, Lawrence, Kansas.

Lacaze-Duthiers, H. de (1870). Sur l'organisation de l'arrosoir Aspergillum javanicum. Compte Rendu, Academie des Sciences, Paris 70: 268-271.

Lacaze-Duthiers, H. de (1883). Anatomie de l'arrosoir (Aspergillum dichotomum, L. Reeve). Archives de Zoologie Expérimentale et Générale 2: 1-68.

Lamprell, K. and Healy, J. (1998). Bivalves of Australia, Vol. 2. Backhuys, Leiden.

Lamy, E. (1923). Les Clavagelles et arrosoirs de la Mer Rouge (d'apres les materiaux recueillis par de la Dr. Josseaume). Bulletin du Muséum National d'Histoire Naturelle, Paris 29: 104-107

Morton, B. (1981). The Anomalodesmata. Malacologia 21: 35-60.

Morton, B. (1984a). Adventitious tube construction in Brechites vaginiferus (Bivalvia: Anomalodesmata: Clavagellacea) with an investigation of the juvenile of "Humphreyia strangei". Journal of Zoology, London 203: 461-484.

Morton, B. (1984b). The biology and functional morphology of Clavagella australis (Bivalvia: Anomalodesmata). Journal of Zoology, London 202: 489-511.

Morton, B. (1985a). Adaptive radiation in the Anomalodesmata. In: E.R. Trueman and M.R. Clark (eds.), The Mollusca, Vol. 10, Evolution: 405-459. Academic Press, Sydney.

Morton, B. (1985b). Statocyst structure in the Anomalodesmata (Bivalvia). Journal of Zoology, London 206: 23-34.

Morton, B. (2002a). Biology and functional morphology of the watering pot shell Brechites vaginiferus (Bivalvia: Anomalodesmata: Clavagelloidea). Journal of Zoology, London 257: 545-562.

Morton, B. (2002b). The biology and functional morphology of Humphreyia strangei (Bivalvia: 
Anomalodesmata: Clavagellidae): an Australian cemented 'watering pot' shell. Journal of Zoology, London 258: 11-25.

Morton, B. (2003a). The biology and functional morphology of Bentholyonsia teramachii (Bivalvia: Lyonsiellidae): clues to the origin of predation in the deep-water Anomalodesmata. Journal of Zoology, London 261: 363-380.

Morton, B. (2003b). The biology and functional morphology of Dianadema gen. nov. multangularis (Tate, 1887) (Bivalvia: Anomalodesmata: Clavagelloidea). Journal of Zoology, London 259: 389-401.

Morton, B. (2004a). The biology and functional morphology of Foegia novaezelandiae (Bivalvia: Anomalodesmata: Clavagelloidea) from Western Australia. Malacologia 46: 37-55.

Morton, B. (2004b). The biology and functional morphology of Kendrickiana gen. nov. veitchi (Bivalvia: Anomalodesmata: Clavagelloidea). Invertebrate Biology 123: 244-259.

Morton, B. (2004c). The biology and functional morphology of Nipponoclava gigantea (Bivalvia: Anomalodesmata): clues to the origin of tube dwelling in the Penicillidae. Journal of Zoology, London 264: 1-15.

Morton, B. (2006). The structure and formation of the adventitious tube of the Japanese watering pot shell Stirpulina ramosa (Bivalvia: Anomalodesmata: Clavagellidae) and a comparison with that of the Penicillidae. Invertebrate Biology [In press].

Owen, R. (1835). On the anatomy of Clavagella Lam. Transactions of the Zoological Society of London 1: 269-274.

Pojeta, J. and Sohl, N.F. (1987). Ascaulocardium armatum (Morton, 1833), new genus (Late Cretaceous): the ultimate variation on the bivalve paradigm. Paleontological Society Memoirs 24: 1-77.

Prezant, R.S. (1979a). Shell spinules of the bivalve Lyonsia hyalina (Bivalvia: Anomalodesmata). Nautilus 93: 93-95.

Prezant, R.S. (1979b). The structure and function of the radial mantle glands of Lyonsia hyalina (Bivalvia: Anomalodesmata). Journal of Zoology, London 187: 505-516.

Prezant, R.S. (1981). Comparative shell ultrastructure of lyonsiid bivalves. The Veliger 23: 289-299.

Purchon, R.D. (1956). A note on the biology of Brechites penis (L.). Lamellibranchia. Zoological Journal of the Linnean Society 43: 43-54.
Purchon, R.D. (1960). A further note on the biology of Brechites penis (L.). Lamellibranchia. Proceedings of the Malacological Society of London 34: 19-23.

Reeve, L. (1860). Conchologica Iconica, 12 Aspergillum, London.

Savazzi, E. (1982). Adaptations to tube dwelling in the Bivalvia. Lethaia 15: 275-297.

Savazzi E. (1999). Boring, nestling and tube-dwelling bivalves. In E. Savazzi (ed), Functional Morphology of the Invertebrate Skeleton, 205-237. Wiley \& Sons, Chichester.

Savazzi, E. (2000). Morphodynamics of Bryopa and the evolution of clavagellids. In E.M. Harper, J.D. Taylor and J.A. Crame (eds), The Evolutionary Biology of the Bivalvia. Geological Society, London, Special Publications 177: 313-327.

Smith, B.J. (1971). A revision of the family Clavagellidae (Pelecypoda: Mollusca) from Australia with descriptions of two new species. Journal of the Malacological Society of Australia 2: 135-161.

Smith, B.J. (1976). Revision of the recent species of the family Clavagellidae (Mollusca: Bivalvia). Journal of the Malacological Society of Australia 3: 187-209.

Smith, B.J. (1978). Further notes on the Clavagellidae, with speculation on the process of tube growth. Journal of the Malacological Society of Australia 4: 77-79.

Smith, B.J. (1998). Family Clavagellidae. In P.L. Beesley, G.J.B. Ross and A. Wells (eds), Mollusca: The Southern Synthesis. Fauna of Australia. Vol. 5. Part A, 413-415. CSIRO Publishing, Melbourne.

Soliman, G.N. (1971). On a new clavagellid bivalve from the Red Sea. Proceedings of the Malacological Society of London 39: 389-397.

Stasek, C.R. (1963). Synopsis and discussion of the association of ctenidia and labial palps in the bivalved molluscs. The Veliger 6: 91-97.

Taylor, J.D., Kennedy, W.J. and Hall, A. (1973). The shell structure and mineralogy of the Bivalvia II. Lucinacea - Clavagellacea. Conclusions. Bulletin of the British Museum (Natural History), Zoology 22: 235-294.

Yonge, C.M (1982). Mantle margins with a revision of siphonal types in the Bivalvia. Journal of Molluscan Studies 48: 102-103.

Manuscript received 3 February 2005; accepted 7 February 2006 


\section{APPENDIX}

\begin{tabular}{|c|c|c|c|}
\hline $\mathrm{AA}$ & Anterior adductor muscle & OP & Outer layer of periostracum \\
\hline AN & Anus & OV & Ovary \\
\hline \multirow[t]{2}{*}{$\mathrm{APR}$} & Anterior pedal retractor muscle (or & $\mathrm{P}$ & Periostracum \\
\hline & impression) & PD & Pedal disc \\
\hline ASM? & Anterior suspensory muscle? & PE & Papilla epithelium \\
\hline AU & Auricle & PEG & Periostracal groove \\
\hline CA & Ctenidial axis & PEN & Pedal nerve \\
\hline CAN & Ctenidial axis nerve & PG & Pedal gape \\
\hline C) & Cuticular junction & PN & Pallial nerve \\
\hline CM & Circular muscle layer & PPD & Papilla of pedal disc \\
\hline C-P-V-CONN & Cerebro-pleural visceral connective & PPDR & Papilla of pedal disc rim \\
\hline DD & Digestive diverticula & PPR & Posterior pedal retractor muscle \\
\hline DK & Distal limb of the kidney & $\operatorname{PRM}(1)$ & Pallial retractor muscle (or impression) \\
\hline ES & Exhalant siphon & PRM(2) & Papillate pallial retractor muscle (or \\
\hline $\mathrm{F}$ & Foot & & impression) \\
\hline FPA & Fourth pallial aperture & $\operatorname{PPRM}(2)$ & Papilla of pallial retractor muscle (or \\
\hline $\mathrm{H}$ & Heart & & impression) \\
\hline $\mathrm{HA}$ & Haemocoel & $\mathrm{R}$ & Rectum \\
\hline HG & Hypobranchial gland & RSBC & Roof of the supra-branchial chamber \\
\hline ID & Inner demibranch & $\mathrm{S}$ & Siphons \\
\hline IE & Inner epithelium & SA & Shell saddle (or impression) \\
\hline ILP & Inner labial palp & SBC & Supra-branchial chamber \\
\hline IP & Inner layer of periostracum & SG & Siphonal gland \\
\hline IS & Inhalant siphon & SN & Siphonal nerve \\
\hline K & Kidney & SP & Siphonal papilla \\
\hline LM & Longitudinal muscle & SRM & Siphonal retractor muscles \\
\hline M & Mantle & ST & Statocyst \\
\hline $\mathrm{MF}$ & Muscle fibres & STA & Statoconia \\
\hline $\mathrm{O}$ & Oesophagus & SV & Shell valve (or impression) \\
\hline OD & Outer demibranch & TE & Testes \\
\hline $\mathrm{OE}$ & Outer epithelium & TMF & Transverse muscle fibres \\
\hline OLP & Outer labial palp & $\mathrm{V}$ & Ventricle \\
\hline OMF & Oblique muscle fibres & VG & Visceral ganglia \\
\hline
\end{tabular}

